\title{
An Anatomical Basis for Visual Calibration of the Auditory Space Map in the Barn Owl's Midbrain
}

\author{
Daniel E. Feldman and Eric I. Knudsen \\ Department of Neurobiology, Stanford University School of Medicine, Stanford, California 94305-5401
}

The map of auditory space in the external nucleus of the inferior colliculus (ICX) of the barn owl is calibrated by visual experience during development. ICX neurons are tuned for interaural time difference (ITD), the owl's primary cue for sound source azimuth, and are arranged into a map of ITD. When vision is altered by rearing owls with prismatic spectacles that shift the visual field in azimuth, ITD tuning in the ICX shifts adaptively. In contrast, ITD tuning remains unchanged in the lateral shell of the central nucleus of the inferior colliculus (ICCls), which provides the principal auditory input to the ICX, suggesting that the projection from the ICCls to the ICX is altered by prism-rearing.

In this study, the topography of the ICCls-ICX projection was assessed in normal and prism-reared owls by retrograde label- ing using biotinylated dextran amine. In juvenile owls at the age before prism attachment, and in normal adults, labeling patterns were consistent with a topographic projection, with each ICX site receiving input from a restricted region of the ICCls with similar ITD tuning. In prism-reared owls, labeling patterns were systematically altered: each ICX site received additional, abnormal input from a region of the ICCls where ITD tuning matched the shifted ITD tuning of the ICX neurons. These results indicate that anatomical reorganization of the ICCls-ICX projection contributes to the visual calibration of the ICX auditory space map.

Key words: sound localization; inferior colliculus; experiencedependent plasticity; biotinylated dextran amine; Tyto alba; development
In the CNS, the mature representation of sensory stimuli is influenced powerfully by sensory experience early in life. Neuronal stimulus selectivity can be altered dramatically when animals are reared with altered visual (Wiesel and Hubel, 1963; Udin and Fawcett, 1988; Knudsen and Brainard, 1991), somatosensory (Fox, 1994), or auditory experience (Knudsen, 1985; King, 1993). Such changes in stimulus selectivity in turn may produce largescale alterations in sensory maps (e.g., LeVay et al., 1980; Knudsen and Brainard, 1991). Increasing evidence indicates that physical rearrangement of synaptic inputs onto central neurons is responsible in part for such plasticity. For example, ocular dominance changes that occur in the primary visual cortex after monocular deprivation are likely to reflect the rearrangement of the geniculocortical arbors that provide input to cortical neurons (Antonini and Stryker, 1993a). Here we investigate a possible anatomical basis for another well studied example of experiencedependent plasticity, the visual calibration of the auditory space map in the barn owl's optic tectum (OT).

Spatial location is represented in the auditory system by neurons tuned for acoustic cues that vary with sound source location. In barn owls, neurons in the OT form a map of auditory space based on their tuning for interaural time difference (ITD) and interaural level difference (ILD), the primary cues for sound source azimuth and elevation, respectively (Moiseff and Konishi, 1981; Olsen et al., 1989). The selectivity of tectal neurons for

Received Feb. 4, 1997; revised June 6, 1997; accepted June 20, 1997.

This work was supported by Grant 5 R01 DC 00155-17 from the National Institute of Deafness and Communication Disorders, National Institutes of Health, and by a

Howard Hughes Predoctoral Fellowship to D.E.F. We thank Dr. Carla Shatz for critical comments on an earlier version of this manuscript.

Dr. Feldman's present address: Department of Psychiatry, Langley Porter Psychiatric Institute, Box 0984, University of California, San Francisco, CA 94143.

Correspondence should be addressed to Dr. Eric I. Knudsen, Department of Neurobiology, Fairchild Building, Stanford University School of Medicine, Stanford, CA 94305-5401.

Copyright (C) 1997 Society for Neuroscience $\quad 0270-6474 / 97 / 176820-18 \$ 05.00 / 0$ these auditory localization cues, and thus the topography of the auditory space map itself, is greatly influenced by early auditory and visual experience (Knudsen, 1985; Brainard and Knudsen, 1995b). For example, when visual and auditory worlds are experimentally misaligned by rearing owls wearing prismatic spectacles that displace the visual field in azimuth, tectal neurons acquire responses to ITDs corresponding to the displaced visual receptive fields (VRFs) and abandon responses to normal ITDs, resulting in a shift in ITD tuning (Fig. 1) (Brainard and Knudsen, 1993). The result of this visual calibration of ITD tuning, which takes several weeks to occur (Brainard and Knudsen, 1995a), is to maintain the alignment between auditory and visual maps of space in the tectum (Knudsen and Brainard, 1991).

This visually guided adjustment of tectal ITD tuning reflects plasticity occurring in the external nucleus of the inferior colliculus (ICX), which provides auditory input to the OT. The ICX receives its principal auditory input from a subdivision of the central nucleus of the inferior colliculus, the lateral shell (ICCls) (Fig. 2A). The ICCls, ICX, and OT contain maps of ITD (Wagner et al., 1987; Brainard and Knudsen, 1993) and are linked in series by feedforward topographic projections (Knudsen and Knudsen, 1983; Wagner et al., 1987). When owls are reared with displacing prisms, ITD tuning is altered in both the ICX and the OT, but not in the ICCls, indicating that the site of synaptic modification is either in the ICX itself or in the projection from the ICCls to the ICX (Brainard and Knudsen, 1993). In this study, we examined the topography of the ICCls-ICX projection in normal and prism-reared owls, using small injections of the retrograde tracer biotinylated dextran amine (BDA). We found that the topography of this projection is altered by prism-rearing in a manner that can explain much of the ITD tuning modification that takes place in the ICX.

Some of these results have been published previously in abstract form (Feldman and Knudsen, 1994, 1996). 

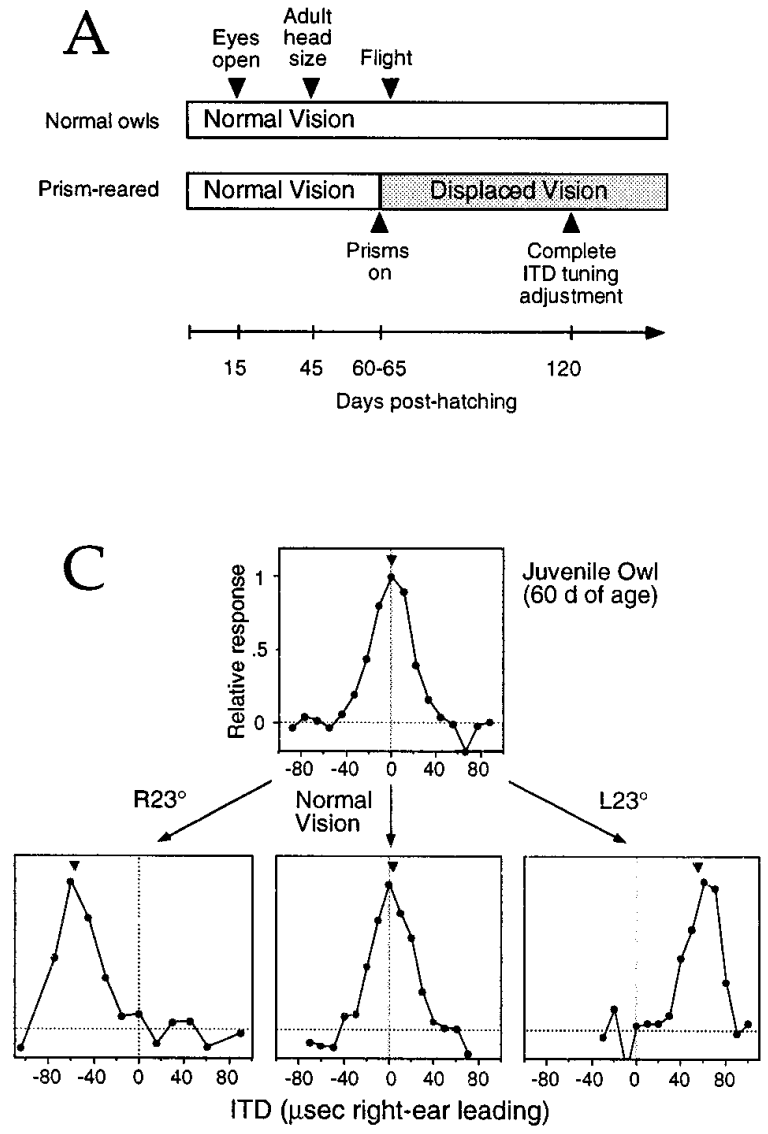

B
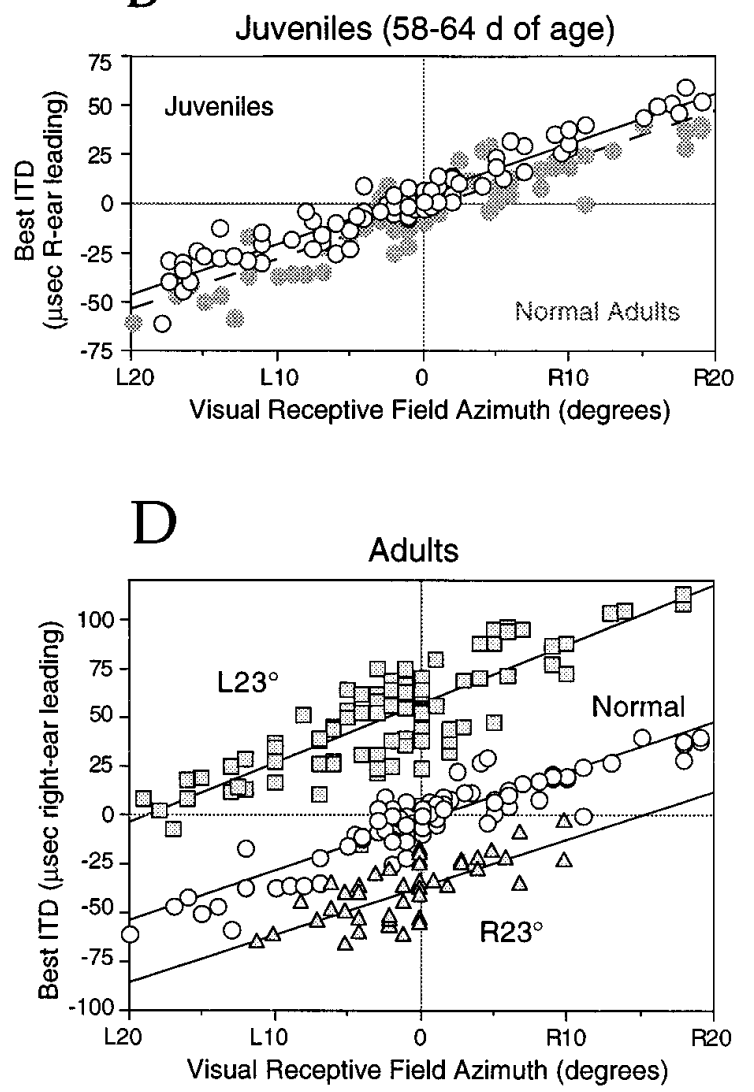

Figure 1. Modification of tectal ITD tuning by prism-rearing from $60 \mathrm{~d}$ of age. $A$, Prism-rearing protocol, with various developmental milestones indicated. $B$, Relationship between best ITD and VRF azimuth for tectal units in three juvenile owls (open circles and solid regression) and 21 normal adult owls (gray symbols and dashed regression). Normal adult data are pooled across two owls in the current study and 19 owls from previous studies (Mogdans and Knudsen, 1992; Brainard and Knudsen, 1993). There was no significant difference between the two regressions ( $t$ test for slopes: $t=0.36$, $\mathrm{df}=210, p>0.25$; for intercepts: $t=0.76, \mathrm{df}=211, p>0.10$; Zar, 1996). $C$, Modification of ITD tuning for units with VRFs at $0^{\circ}$ azimuth. Curves are from representative units in juvenile, normal adult, and prism-reared owls after complete ITD tuning shift. Triangles, Best ITD. D, Relationship between best ITD and VRF azimuth for owls reared from 60-65 d of age with L23 prisms ( 7 owls), R23 ${ }^{\circ}$ prisms ( 3 owls), or normal vision ( 21 owls). Lines indicate linear regressions.

\section{MATERIALS AND METHODS}

Anatomical measurements were made in four normal adult owls, three juvenile owls 56-64 d of age, and six prism-reared owls (see Table 1). Three additional prism-reared owls and one additional juvenile were used in electrophysiological experiments to characterize the ITD tuning shift and confirm the site of plasticity in the ICX.

Prism-rearing. The protocol for prism-rearing is shown in Figure $1 \mathrm{~A}$. Owls were reared with normal visual experience until 60-65 $\mathrm{d}$ of age, when the skull and facial ruff have reached adult size (Knudsen et al., 1984; Haresign and Moiseff, 1988). Spectacles with Fresnel prismatic lenses ( 40 diopters, Vision Care $/ 3 \mathrm{M}$ ) that displaced the visual field by $23^{\circ}$ to the right or left were then fitted to a plate cemented to the skull while the bird was anesthetized with $2 \%$ halothane in nitrous oxide/oxygen (4:5). The prisms displaced a region of the visual field measuring $45-60^{\circ}$ in azimuth and $45-55^{\circ}$ in elevation, centered on the visual axis (Brainard and Knudsen, 1993). During the same procedure, a small head bolt was fixed to the skull. When owls became mature enough to fly (2-7 d after prism mounting), they were placed in large flight cages with other owls for maximal visual and auditory stimulation.

After prism attachment at 60-65 d of age, ITD tuning becomes modified gradually over the course of several weeks, with maximal ITD tuning adjustment occurring by $120 \mathrm{~d}$ of age (Feldman, 1997). In this study, all physiological and anatomical measurements were made at $\geq 160$ $\mathrm{d}$ of age, after complete tuning adjustment had taken place.

Physiological recording procedures. Owls were prepared for multiple electrophysiology experiments. At the start of each experiment, owls were given a $3 \mathrm{cc}$ subdermal injection of $2.5 \%$ dextrose in $0.45 \%$ sterile saline, anesthetized with the halothane/nitrous mixture, wrapped in a soft leather restraint, and attached by means of the head bolt to a stereotaxic device. The skull was aligned using retinal landmarks, and a small craniotomy made previously over the OT and inferior colliculus (IC) was reopened. Extracellular unit recordings were made using epoxylite-covered tungsten electrodes (1-2.5 $\mathrm{M} \Omega$ at $1 \mathrm{kHz})$. Owls were anesthetized with a nitrous oxide/oxygen mixture in the minimum ratio needed to maintain anesthesia (2:5-4:5), and when required the halothane/nitrous mixture was reapplied briefly. At the end of the recording session, the craniotomy was irrigated with chloramphenicol $(0.5 \%)$ and sealed with dental acrylic, and the owl was kept in an observation cage until it had fully recovered (overnight). Initial experiments in each owl were performed to assess the extent of ITD tuning modification; in a final experiment, retrograde tracer was injected.

Auditory measurements. Auditory responses were characterized as described previously (Feldman and Knudsen, 1994). Briefly, auditory stimuli were generated digitally and presented dichotically through earphones (Knowles ED-1941) coupled to damping assemblies (BF-1743) placed in the ear canals. Earphones were matched within $1 \mathrm{~dB}$ from 2 to $12 \mathrm{kHz}$. Stimuli were either tone or "broad band" noise bursts (50 msec duration; $5 \mathrm{msec}$ rise/fall time for tones; $0 \mathrm{msec}$ rise/fall time for noise). Broad band noise bursts were highpass-filtered at $4 \mathrm{kHz}$ to minimize sound propagation through the interaural canal (Moiseff and Konishi, 1981) and had flat frequency spectra $(<2 \mathrm{~dB}$ rolloff in the $4-12 \mathrm{kHz}$ range). Stimuli were presented at $20-30 \mathrm{~dB}$ above unit threshold.

Multiunit (typically two to four units) tuning for ITD or ILD was determined by presenting a series of broad band noise bursts in which 

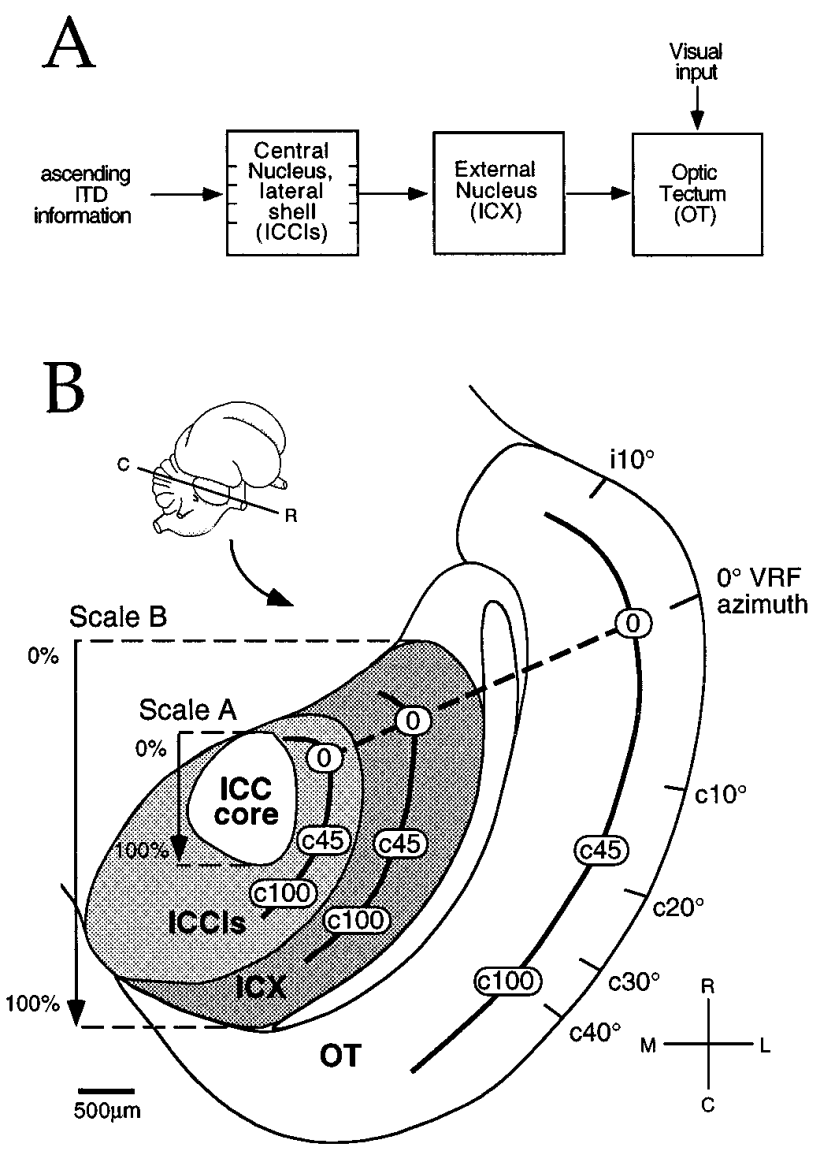
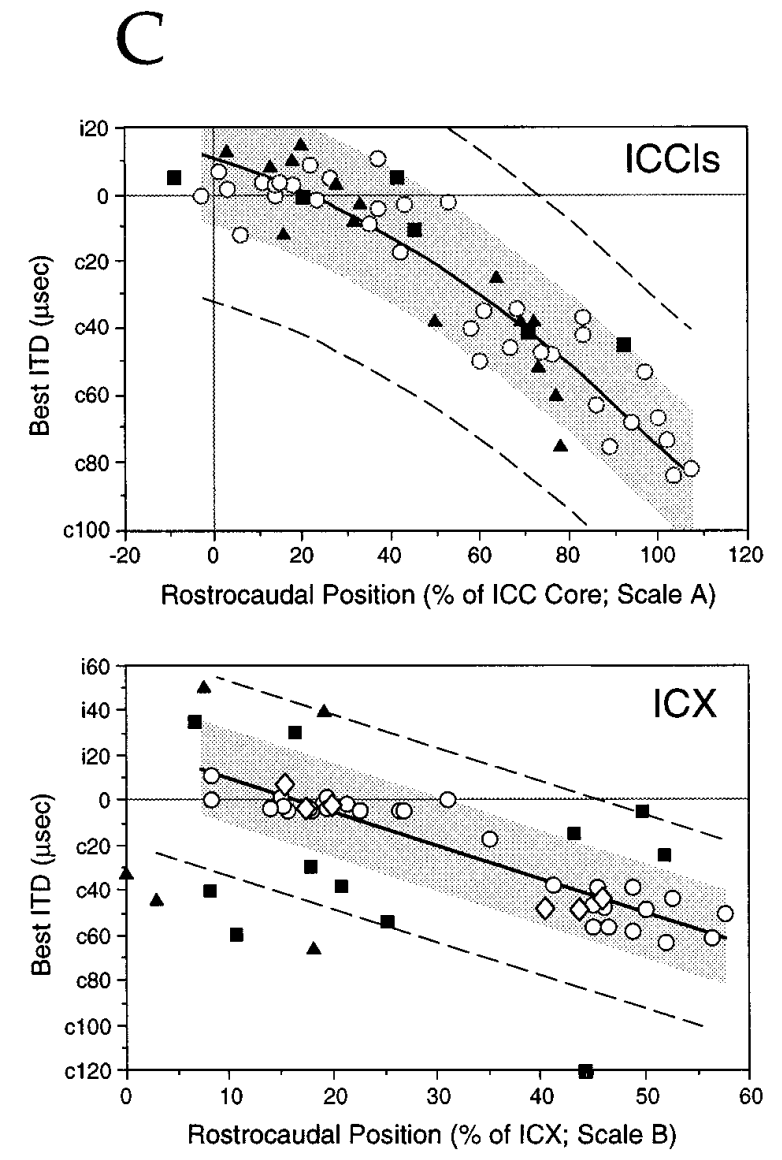

Figure 2. Representation of ITD in the IC of normal and prism-reared barn owls. $A$, ITD pathway leading to the Optic Tectum (OT). Each nucleus contains a map of ITD, and nuclei are linked in series by feedforward projections that are topographic in the horizontal plane (Knudsen and Knudsen, 1983; Wagner et al., 1987). B, Representation of ITD in the ICCls, ICX, and OT. Ovals denote locations of neurons tuned to 0, 45, and 100 $\mu$ sec contralateral-ear leading ITD. The tectal map of visual azimuth, in degrees ipsilateral or contralateral to the vertical meridian, is also shown (Olsen et al., 1989). Thick dashed line, 0 Transect (see Materials and Methods). C, Maps of best ITD in the ICCls and ICX of normal and prism-reared owls. Circles, Recording sites from normal adults. Diamonds, Juvenile owls. Triangles, Owls prism-reared from eye opening (Brainard and Knudsen, 1993). Squares, Owls prism-reared from $60 \mathrm{~d}$ of age (present study). On the ordinate, $i$ and $c$ denote ipsilateral- and contralateral-ear leading ITDs. Least-squares regressions for normal owls: ICCls, $y=-0.002 x^{2}-0.68 x+14.5 ; r^{2}=0.916 ; p<0.0001$. ICX, $y=25-1.5 x ; r^{2}=0.884 ; p<0.0001$. Gray area, Envelope of normal data. Dashed lines, Predicted regressions for an ITD tuning shift equal in magnitude to that observed in the OT (43 $\mu$ sec).

ITD or ILD was varied in a random order. Tuning for frequency was determined by presenting a series of tone bursts in which frequency was varied in a random order. Tuning curves were constructed from 10-100 repetitions of the ITD, ILD, or frequency series. Unit responses were defined as the number of spikes occurring in the $100 \mathrm{msec}$ after stimulus onset minus the number occurring in the $100 \mathrm{msec}$ before stimulus onset (baseline activity). The width of tuning was defined as the continuous range of ITD, ILD, or frequency for which the response of the unit exceeded $50 \%$ of the maximum response. Best ITD, best ILD, and best frequency were defined as the midpoint of this range. ITD tuning was measured with ILD held constant at the best value, and ILD tuning was measured with ITD held constant at the best value. Best frequency was measured with ITD and ILD held constant at their best values.

Physiological identification of the ICCls, ICX, and OT. Neuronal tuning for ITD, ILD, and frequency was used to identify IC subdivisions (Brainard and Knudsen, 1993; Feldman and Knudsen, 1994). Briefly, ICCls units were narrowly tuned for frequency (median tuning width of units within a penetration was $<2.4 \mathrm{kHz}$ ), were usually tuned for ILD, and responded strongly to ITD values separated by integer multiples of the unit's best frequency (i.e., ITD values representing equivalent phase differences) (Wagner et al., 1987). In dorsoventral penetrations, best frequency progressed from low to high values, and a single value of ITD; produced near-optimal responses in all units (the "array-specific ITD"; Wagner et al., 1987). Best ITDs for ICCls sites were based on the ITD tuning peak closest to the array-specific ITD.

In contrast, ICX units had broad frequency tuning (median width in a penetration $>2.5 \mathrm{kHz}$ ). In a dorsoventral penetration, best frequency remained constant, whereas best ILD progressed from right-ear greater to left-ear greater, and units were tuned for a single best value of ITD. OT units were characterized by visual responses and spontaneous bursting in the superficial layers. These physiological characteristics have been confirmed by anatomical reconstruction of recording sites in each nucleus (Brainard and Knudsen, 1993).

The 0 and c45 Transects. For many experiments, a series of electrode penetrations was made along a transect connecting the representation of $0 \mu \mathrm{sec}$ ITD in the ICCls with that of $0^{\circ}$ visual azimuth in the OT (the " 0 Transect," dashed line in Fig. 2B). Because prism-rearing alters neither the representation of ITD in the ICCls (see Results) nor that of visual space in the OT (Brainard and Knudsen, 1993), the 0 Transect passes through the same anatomical locations in normal and prism-reared owls. Therefore, we were able to use this transect to target recordings and tracer injections to anatomically matched sites in the ICX of normal and prism-reared owls. Injections at a more caudal ICX location were targeted using a similar "c45 Transect," which connected the representations of $45 \mu \mathrm{sec}$ contralateral-ear leading (c45 $\mu \mathrm{sec}$ ) ITD in the ICCls and $\mathrm{c} 18^{\circ}$ visual azimuth in the OT.

Injection of $B D A$. For retrograde labeling experiments, a glass electrode $(1.0 \mathrm{~mm}$ borosilicate glass, $15-20 \mu \mathrm{m}$ tip) containing $10 \%$ BDA $(10,000 \mathrm{MW}$; Molecular Probes, Eugene, OR) in $0.14 \mathrm{M} \mathrm{KCl}$ with $0.12 \%$ Triton X-100 was placed at a desired site in the ICX. In juveniles and normal adults, injections were made at ICX locations representing either 0 or c45 $\mu \mathrm{sec}$ ITD. In prism-reared owls, injections were made at the same anatomical locations, although ITD tuning at those locations had been modified by prism-rearing. In all owls, injections were targeted by 
moving the BDA electrode laterally along either the 0 Transect or the $\mathrm{c} 45$ Transect until the approximate mediolateral center of the ICX was found (normal), or until ICX sites with large ITD tuning shifts were found (prism-reared). Once an appropriate site was located, ITD tuning was documented, and BDA was applied at two sites separated dorsoventrally by $200-300 \mu \mathrm{m}$ (for each site, $3 \mu \mathrm{A}$ positive current, $7 \mathrm{sec}$ on $7 \mathrm{sec}$ off, for 5 min).

After 3-5 d survival, owls were deeply anesthetized with the halothane/nitrous oxide mixture. Nembutal $(30 \mathrm{mg} / \mathrm{kg}$ ), lidocaine $\mathrm{HCl}(12$ $\mathrm{mg} / \mathrm{kg}$ ), and heparin (300 U) were injected into the left cardiac ventricle, and owls were perfused transcardially with $0.1 \mathrm{M}$ phosphate buffer $\left(\mathrm{PO}_{4}\right.$ buffer, $\mathrm{pH} 7.4$ ), followed by $4 \%$ paraformaldehyde in $\mathrm{PO}_{4}$ buffer as fixative. The brain was removed, sunk in $30 \%$ sucrose in $4 \%$ paraformaldehyde, and sectioned at $40 \mu \mathrm{m}$ intervals in the horizontal plane defined by the long axis of the OT (Fig. $2 B$ ).

Visualization of labeled neurons and fibers. BDA labeling was visualized using a standard diaminobenzidine (DAB) reaction. Sections were rinsed in $\mathrm{PO}_{4}$ buffer, and endogenous peroxidases were quenched in $10 \%$ methanol and $1 \% \mathrm{H}_{2} \mathrm{O}_{2}$ in $\mathrm{PO}_{4}$ buffer. Sections were then incubated for $60 \mathrm{~min}$ at room temperature in a solution of avidin-biotin-peroxidase complex (Elite kit, Vector Laboratories, Burlingame, CA), rinsed sequentially in $\mathrm{PO}_{4}$ buffer and Tris-imidazole buffer (Tris-imid, $\mathrm{pH} 7.2$ ), and then developed for $20 \mathrm{~min}$ in $0.4 \%$ DAB in Tris-imid with $0.003 \%$ $\mathrm{H}_{2} \mathrm{O}_{2}$. Signal was enhanced by a 2 min incubation in $50 \%$ DAB Enhancing Solution (Vector). In some cases, sections were lightly Nissl counterstained before they were dehydrated and coverslipped. In a few cases, $0.1 \%$ Triton X-100 was included in the avidin-biotin-peroxidase incubation for darker staining. The addition of Triton X-100 did not alter the number or distribution of labeled ICCls neurons, when compared with alternate sections in which Triton X-100 was not used.

Every third section was stained with an antibody to a calcium binding protein $(\mathrm{CaBP})$ that immunostains the ICC core and the lateral rim of the ICX (Takahashi et al., 1987). The antibody (7E4 F2) was supplied by Dr. C. E. Carr (University of Maryland). The antibody was visualized using a biotinylated secondary antibody and a subsequent avidin-biotinDAB reaction (Elite kit, Vector). This procedure also resulted in visualization of the BDA injection site.

Anatomical definition of IC subdivisions. In CaBP-stained sections, the ICCls was defined as the area between the lateral edge of the darkly stained ICC core and points $600 \mu \mathrm{m}$ lateral to this edge, measured normal to the core border (Fig. 3). This lateral boundary (which is the boundary between the ICCls and the ICX) was chosen because in a previous study recording sites medial of this boundary were shown to have physiological properties of the ICCls, whereas sites lateral to this boundary had properties of the ICX (data from seven normal colliculi; Brainard and Knudsen, 1993). Defined in this manner, the ICCls occupied an area coincident with the zone of diminished $\mathrm{CaBP}$ immunostaining previously shown to mark the ICCls in intensely stained sections (Takahashi et al., 1987; Takahashi and Konishi, 1988). This region also exhibited the cytoarchitectonic characteristics of the ICC in cresyl violetstained tissue (Knudsen, 1983).

A previous study noted ICX-like physiological properties in a small rostral zone within the current definition of the ICCls (Brainard and Knudsen, 1993). This zone, which lies rostral to the rostral tip of the core and $<600 \mu \mathrm{m}$ from the edge of the core, is clearly within the central nucleus on the basis of $\mathrm{CaBP}$ staining, cytoarchitectonics, and lack of tectal-projecting neurons (Fig. 3). We therefore consider this rostral zone to be part of the ICCls in this report.

The ICX was defined as the region of the IC immediately lateral to the ICCls. The lateral boundary of the ICX was defined by the lateral edge of CaBP staining (arrowheads in Fig. 3A) (Takahashi et al., 1987).

Plotting labeled ICCls neurons. For each BDA-stained section, labeled neuronal somata in the IC and labeled varicosity-containing axon segments in the OT were plotted by camera lucida. Cell profiles were identified as labeled somata if they showed typical soma morphology and had at least one proximal dendrite. Each soma was assigned to an IC subdivision based on boundaries determined from the adjacent $\mathrm{CaBP}$ stained section. For this study, only those ICCls somata contained in sections in which the ICX was present were considered, because the map of ITD in the ICCls is best described in this region, which corresponds approximately to the $5-7 \mathrm{kHz}$ frequency laminae in the ICC (Takahashi and Konishi, 1988; Brainard and Knudsen, 1993). The locations of all labeled ICCls neurons within this region, which measures $\sim 1 \mathrm{~mm}$ in dorsoventral extent, were projected from individual camera lucida drawings onto a single composite drawing, using the geometric center of the
ICC core and the rostrocaudal axis for alignment. This alignment method kept subdivision boundaries, the injection site, and the location of labeled terminals in the OT relatively constant across the individual sections. On the composite drawing, subdivision boundaries were drawn from a CaBP-stained section containing the injection site.

The spatial distribution of ICCls neurons labeled by each ICX injection was quantified by calculating the rostrocaudal position of each labeled soma, relative to the ICC core staining in an immediately adjacent $\mathrm{CaBP}$ section, using Scale $\mathrm{A}$ in Figure $2 B$. This resulted in a distribution of cell positions for each case. Distribution width was described by the interquartile range (IQR), defined as the difference in position between 25 th and 75 th percentiles of the distribution. Distributions were compared between cases by ANOVA or $\chi^{2}$ tests. The criterion value for significance was $p<0.05$.

The number of ICCls neurons labeled in juvenile and prism-reared cases was compared by calculating the metric $(P-J) /(P+J)$, where $P=$ average number of labeled neurons in a specific ICCls region in prismreared cases, and $J=$ average number of neurons in that same ICCls region in juvenile cases. Positive values of this metric indicate more labeled neurons per prism-reared case than per juvenile case; negative values indicate more labeled neurons per juvenile case than per prismreared case; a value of 0 indicates equal labeling in both types of cases.

For each case, injection site volume in cubic microns was calculated as $40 \pi \Sigma r_{\mathrm{i}}{ }^{2}$, where $r_{\mathrm{i}}$ was the radius, in microns, of the dense extracellular reaction product at the injection site in each $40 \mu \mathrm{m}$ section.

\section{RESULTS}

This study has two major parts. First, because the prism-rearing protocol used in this study was different from that used in previous reports (Knudsen and Brainard, 1991; Brainard and Knudsen, 1993, 1995a), we describe briefly the modification of ITD tuning caused by prism-rearing with the new protocol. Second, we propose a specific anatomical basis for this plasticity in the projection from the ICCls to the ICX and present the results of retrograde labeling experiments designed to test this hypothesis.

\section{Modification of ITD tuning caused by prism-rearing from 60 days of age}

In this study, prisms were first attached at 60-65 d of age, before which owls experienced normal vision (Fig. $1 A$ ). This protocol was adopted so that we could assess the representation of ITD and the anatomy of the ICCls-ICX projection at the age before prism attachment, allowing us to determine how these properties were modified by subsequent prism-rearing. Measurement of initial physiological and anatomical states is considerably more difficult at the age of eye opening (14-18 d of age), when prisms were attached in previous studies (Brainard and Knudsen, 1993, 1995a).

The initial state of ITD tuning before prism attachment was assayed in three juvenile owls $56-64 \mathrm{~d}$ of age (Fig. $1 B$ ). In these owls, ITD tuning in the OT appeared adult-like in shape and tuning width (mean tuning width for juveniles, $32.5 \pm 8 \mu \mathrm{sec}, n=$ 85 units; for adults, $36.6 \pm 11 \mu \mathrm{sec}, n=74$ units). In addition, the relationship between best ITD and VRF azimuth across OT units was indistinguishable from that in a large group of normal adults (Fig. $1 B$ ), indicating that the topography of the tectal ITD map was already mature at this age.

This initial ITD tuning was modified by subsequent prism experience, as illustrated for tectal units with VRFs located straight in front of the owl $\left(0^{\circ}\right.$ azimuth) in Figure $1 C$. In juveniles and normal adults, units with these VRFs were tuned to ITDs near $0 \mu$ sec. However, in owls reared with $\mathrm{R} 23^{\circ}$ prisms, ITD tuning at this same tectal location was shifted toward left-ear leading ITDs, and in owls reared with $\mathrm{L} 23^{\circ}$ prisms, tuning was shifted toward right-ear leading ITDs. These tuning changes occurred across a large region of the tectal space map, resulting in a systematic shift in the relationship between best ITD and VRF 

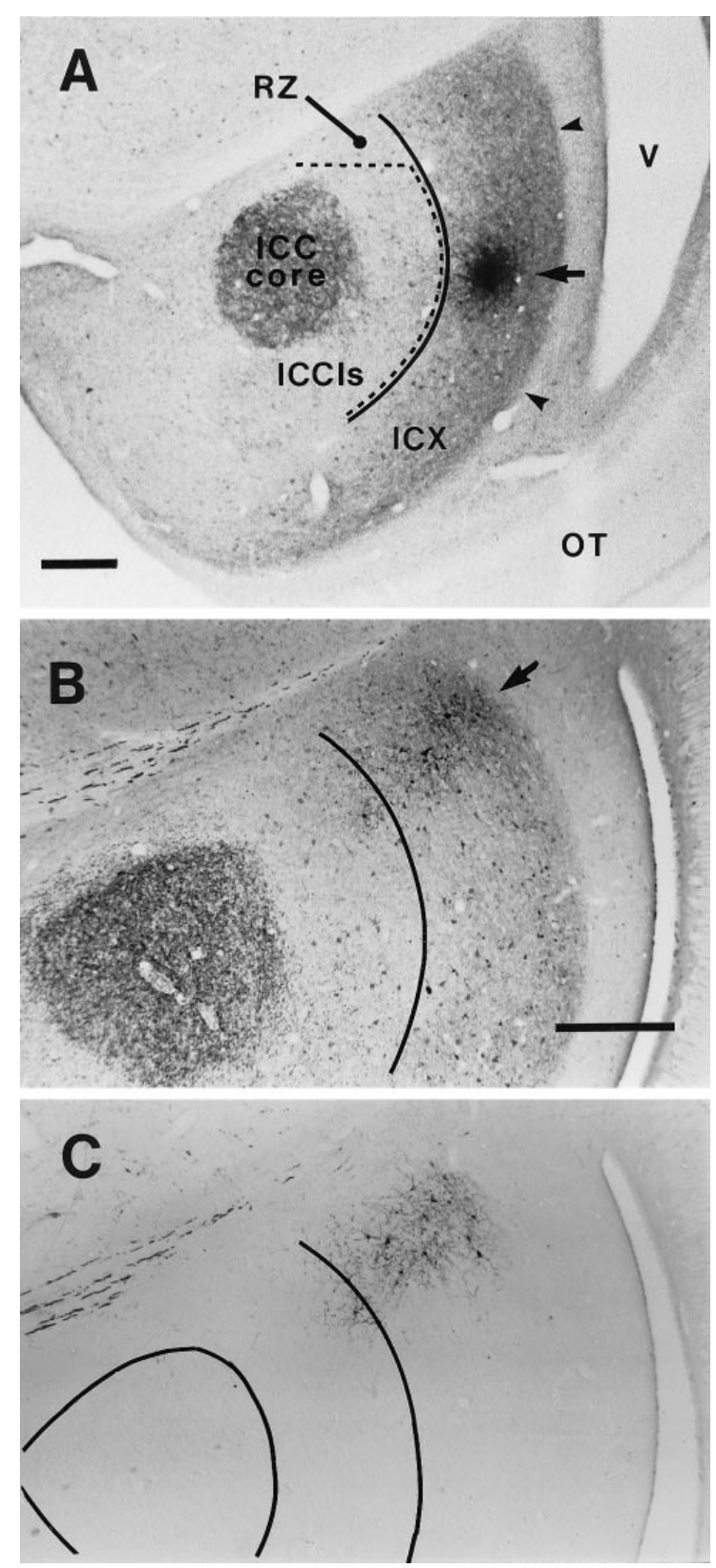

Figure 3. Anatomical definition of the ICCls. A, CaBP-immunostained horizontal section through the IC showing the intensely stained ICC core surrounded by the CaBP-poor region previously identified as the ICCls (Takahashi et al., 1987; Takahashi and Konishi, 1988). Moderate staining is observed in the ICX. Arrow, BDA injection site on the c45 Transect in the ICX (Case 25R); solid line, $600 \mu \mathrm{m}$ from lateral border of ICC core. The cytoarchitectural boundary between ICC and ICX in adjacent cresyl violetstained sections lay within $100 \mu \mathrm{m}$ of the solid line in all cases examined $(n=5$ colliculi). The dotted line encloses the region with physiological properties of the ICCls (from Brainard and Knudsen, 1993). RZ, Rostral zone with anatomical characteristics of the ICCls but ICX-like physiological properties. The caudal border of this zone is located $10 \%$ of the length of the ICC core $(\approx 100 \mu \mathrm{m})$ rostral to the rostral tip of the core (i.e., $-10 \%$ on Scale A, Fig. 2B). Arrowheads, Lateral boundary of ICX. Scale bar, 500 $\mu \mathrm{m}$. Rostral is up and lateral is to the right in this and all figures. $B$, $\mathrm{CaBP}$-stained section containing ICX neurons (arrow) retrogradely labeled by BDA injection into the deep tectal layers at the representation of i5-10 azimuth. Solid line, ICCls/ICX boundary estimated as $600 \mu \mathrm{m}$ from ICC core staining. Scale bar, $500 \mu \mathrm{m}$. $C$, Adjacent BDA-stained section. Labeled neurons were not found in the rostral zone of the ICCls. Subdivision boundaries were projected from the section in $B$. azimuth in prism-reared owls, relative to juveniles and normal adults (Fig. 1D). The magnitude of ITD tuning shift was defined for each recording site in prism-reared owls as the difference between the observed best ITD and that predicted from the VRF using the normal adult regression. Using this measure, the mean tectal ITD tuning shift for the present group of prism-reared owls was $43 \pm 15 \mu \mathrm{sec}$ (SD) ( $n=6$ owls), identical to that observed for owls raised with prisms from eye opening (43 $\pm 14 \mu \mathrm{sec}, n=8$ owls; Brainard and Knudsen, 1993, 1995a).

\section{Site of plasticity in the ICX}

To verify that the site of plasticity for this ITD tuning shift was the ICX, as reported previously for owls reared with prisms from eye opening (Brainard and Knudsen, 1993), we reconstructed the maps of ITD in the ICCls and ICX of normal and prism-reared owls. The maps in normal adults are schematized in Figure 2B, based on data presented below and in Brainard and Knudsen (1993). ITD tuning was measured at recording sites in the ICCls or ICX that were subsequently marked by electrolytic lesion (3 $\mu \mathrm{A}$, tip negative, $10-20 \mathrm{sec}$ ) or by iontophoretic injection of BDA or biocytin. Lesions/injection sites were recovered in horizontal tissue sections (the plane illustrated in Fig. 2B), and position along the rostrocaudal axis was quantified. For ICCls sites, rostrocaudal position was quantified relative to the borders of the ICC core (Fig. $2 B$, Scale $A$ ), which was visualized by staining for $\mathrm{CaBP}$ (see below). On this scale, $0 \%$ denotes the level of the rostral tip of the ICC core; $100 \%$ denotes the level of the caudal tip of the core. Negative values denote positions rostral of the core, and values $>100 \%$ denote positions caudal of the core. For ICX recording sites, position was quantified relative to the boundaries of the ICX (Fig. $2 B$, Scale B). These scales are the same used previously to determine the site of plasticity for owls reared with prisms from eye opening (Brainard and Knudsen, 1993).

For normal adults, the relationship between best ITD and rostrocaudal position in the ICCls (Fig. $2 C$, top, circles) was described well by the polynomial regression:

$$
\text { best } \operatorname{ITD}(\mu \mathrm{sec})=0.002 p^{2}+0.677 p-14.5
$$

where $p=$ rostrocaudal position relative to ICC core staining, and contralateral-ear leading ITD values are positive (data from three normal adult owls from the present study and four from Brainard and Knudsen, 1993). For prism-reared owls, data points fell within the envelope defined by the normal adult data, both for owls reared with prisms from eye opening (Fig. $2 C$, triangles; $n=$ 2 owls; data from Brainard and Knudsen, 1993) and for owls reared with prisms from $60 \mathrm{~d}$ of age (Fig. $2 C$, squares; $n=4$ owls; data from this study). Thus, the map of best ITD in the ICCls was not modified by either prism-rearing protocol.

In contrast, prism-rearing clearly altered the map of ITD in the ICX (Fig. 2C, bottom). In normal adults, this mapping was described by a linear regression between best ITD and rostrocaudal position (Fig. 2C, circles; data from five owls from Brainard and Knudsen, 1993, and four owls from the present study). The same mapping was observed in three juvenile owls (Fig. 2C, diamonds; present study). In contrast, ICX sites in six owls prism-reared from $60 \mathrm{~d}$ (squares) and four owls prism-reared from eye opening (triangles; Brainard and Knudsen, 1993) had best ITD values that were either more contralateral-ear leading than normal (points below the normal regression) or more ipsilateral-ear leading than normal (points above the regression), depending on the direction of the prisms and the laterality of the recording site (see below). 
A

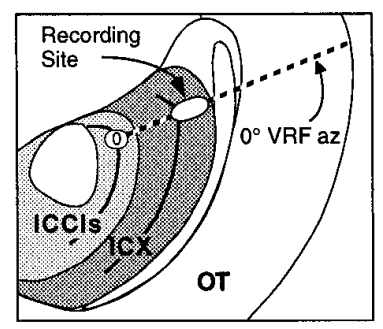

B

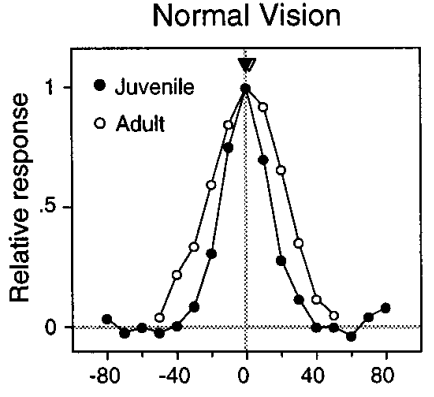

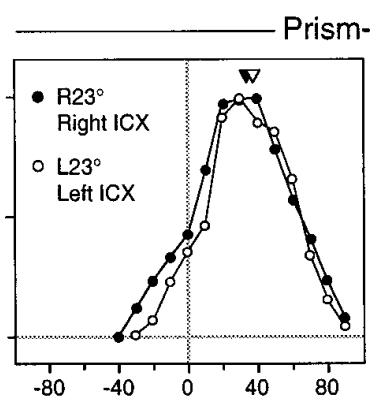

ITD ( $\mu$ sec contra-ear leading)
Prism-Reared

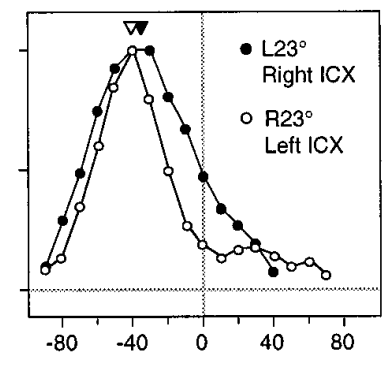

Figure 4. The ITD tuning shift at the normal representation of $0 \mu \mathrm{sec}$ ITD in the ICX. $A$, Targeting of recordings. Recordings were made on the 0 Transect (dashed line) in the lateral half of the ICX (white oval), where the largest tuning shifts are observed after prism-rearing (Brainard and Knudsen, 1993). B, Representative ITD tuning curves recorded at this location in juvenile, normal adult, and prism-reared owls. Triangles, Best ITD.

To quantify the magnitude of ITD shift in the prism-reared cases, we calculated for each recording site the difference between the observed best ITD and the best ITD predicted for that ICX location based on the normal adult regression. For prism-reared owls, the mean difference from the normal regression was $44 \mu \mathrm{sec}$, which was equal to the average ITD tuning shift observed in the OT (43 $\mu \mathrm{sec}$; dashed lines in Fig. $2 C$ ). Owls reared with prisms from eye opening and owls reared with prisms from $60 \mathrm{~d}$ of age showed similar mean differences from the normal regression (53 \pm 13 and $40 \pm 20 \mu \mathrm{sec}$, respectively; $p=0.21$; unpaired $t$ test).

From these data we conclude that prism-rearing from $60-65 \mathrm{~d}$ of age causes modification of ITD tuning in the ICX. The site and extent of plasticity are the same as observed for owls reared with prisms from eye opening (Brainard and Knudsen, 1993, 1995a).

\section{Modification of ITD tuning at a single ICX location during prism-rearing}

In this section, we characterize the ITD tuning modification that occurs at a single ICX location during prism-rearing from 60-65 $\mathrm{d}$ of age to propose a specific anatomical basis for this plasticity. Recordings were made on the 0 Transect (Fig. 4A), which passes through the representation of $0 \mu \mathrm{sec}$ ITD in the ICX of normal owls and through the same anatomical location in prism-reared owls (see Materials and Methods). Recordings were made in the lateral half of the ICX, because the ITD tuning shift is largest in this region (Feldman, 1997), as observed previously in owls reared with prisms from eye opening (Brainard and Knudsen, 1993). In juveniles at the age of prism attachment, and in normal adults, units at this location had best ITDs near $0 \mu \mathrm{sec}$ (Fig. 4B). For juveniles, the mean best ITD at this location was $2 \pm 6 \mu \mathrm{sec}$ contralateral-ear leading ( $n=44$ units, 4 owls); for normal adults, the mean best ITD was $\mathrm{c} 3 \pm 6 \mu \mathrm{sec}$ ( $n=48$ units, 9 owls). ITD tuning widths were slightly narrower in juveniles $(37.8 \pm 7.4 \mu \mathrm{sec}$; $n=44$ units $)$ than in adults $(50.3 \pm 14 \mu \mathrm{sec} ; n=47$ units; $p<$ 0.0001 ; unpaired $t$ test).

Prism experience caused this initial ITD tuning to shift toward left-ear leading ITDs in owls wearing R $23^{\circ}$ prisms, and toward right-ear leading ITDs in owls wearing $\mathrm{L} 23^{\circ}$ prisms. As a result, neurons in the ICX matched to the direction of visual field displacement (e.g., the right ICX in R23 owls) always adopted ITD tuning that was more contralateral-ear leading than normal, whereas neurons in the opposite ICX adopted tuning that was more ipsilateral-ear leading than normal (Fig. 4B). The mean best ITD observed at this location after a contralateral ITD tuning shift was c36 $\pm 13 \mu \sec (n=33$ units, 7 owls $)$; the mean best ITD after an ipsilateral ITD tuning shift was i36 $\pm 21 \mu$ sec $(n=27$ units, 7 owls). Similar tuning shifts occurred at other ICX locations (Fig. 2C).

\section{Hypothesis for an anatomical basis for the ITD tuning shift}

The ICX receives auditory input via a topographic projection from the ICCls (Wagner et al., 1987). In this study, we hypothesized that the topography of this projection confers the map of ITD on the ICX. Because the map of ITD in the ICCls is not altered by prism-rearing (Fig. $2 C$ ), this hypothesis predicts that the ITD tuning shift that occurs in the ICX results from a change in the topography of the ICCls-ICX projection (Fig. 5).

Specifically, we hypothesized that in juveniles and normal adults, ICX neurons tuned to $0 \mu \mathrm{sec}$ ITD would receive input from a restricted set of ICCls neurons at the ICCls representation of $0 \mu \mathrm{sec}$ ITD. Similarly, ICX neurons tuned to c45 $\mu \mathrm{sec}$ ITD would receive input from more caudally located ICCls neurons tuned to $45 \mu \mathrm{sec}$ ITD (Fig. 5, left). The ITD tuning conferred on ICX neurons by this projection would then be relayed to the OT via the topographic projection from the ICX to the OT.

In prism-reared owls, in the ICX in which ITD tuning was shifted toward more contralateral-ear leading ITD values than normal, we predicted that ICX neurons would receive input from abnormally caudal ICCls locations, where these contralateral-ear leading ITDs are represented (Fig. 5, middle). Conversely, in the ICX in which tuning was shifted toward more ipsilateral-ear leading ITD values than normal, we predicted that ICX neurons receive input from abnormally rostral ICCls locations (Fig. 5, right). Because ITD tuning changes in the OT can be completely explained by ITD tuning modification occurring at the level of the ICX (Brainard and Knudsen, 1993), no alteration in the ICX-OT projection was expected.

\section{Injections of BDA}

To test this hypothesis, we made small iontophoretic injections of BDA at physiologically defined sites in the ICX and plotted the locations of retrogradely labeled neurons in the ICCls and anterogradely labeled axon terminals in the OT. Each owl received a single injection in each ICX, with the labeling from each injection site (right and left) constituting a separate case for analysis. Injections were made using standardized iontophoresis parameters and were placed on either the 0 Transect or the c45 Transect (see Materials and Methods).

A typical ICX injection site, on the 0 Transect of a normal 

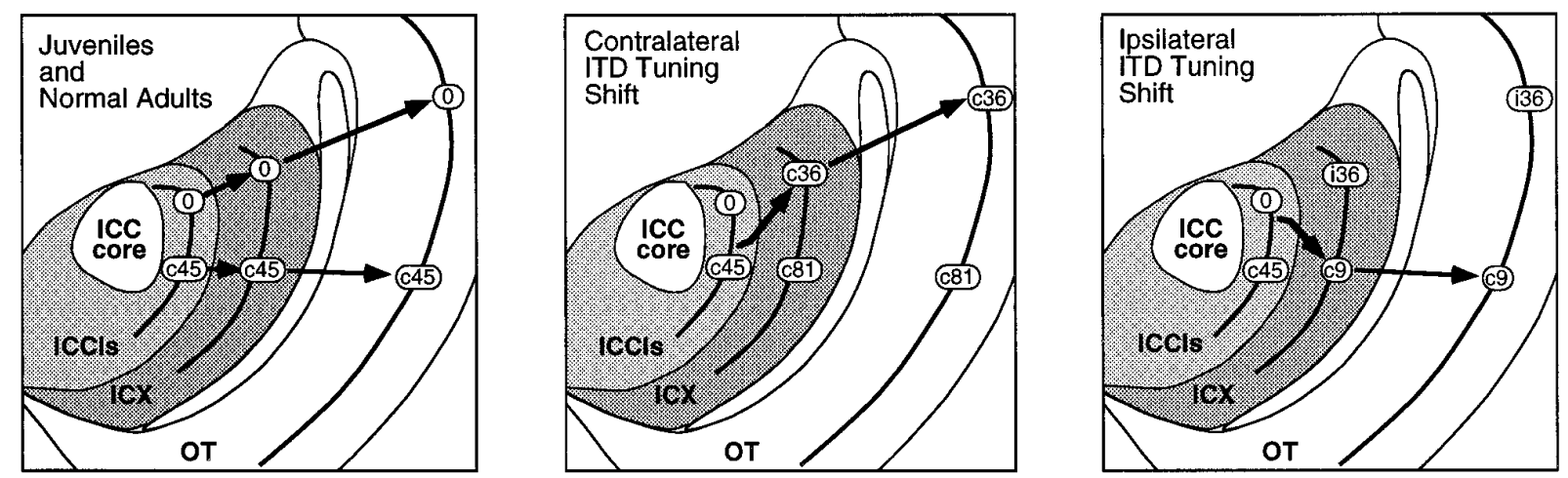

Figure 5. Hypothesis for an anatomical basis for the ITD tuning shift. Left, Normal owls. Known topographic projections from the ICCls to the ICX, and from the ICX to the OT, are hypothesized to be highly precise and to confer ITD tuning on ICX and OT neurons. Middle, Topographic projections after a contralateral ITD tuning shift in the ICX. Neurons on the 0 Transect have become tuned to a mean best ITD of $36 \mu$ sec contralateral-ear leading. These responses are predicted to result from abnormal inputs from ICCls neurons encoding c36 $\mu$ sec ITD (arrow). In this model, ITD tuning in the OT passively reflects changes occurring in the ICX, so no modification is expected in the ICX-OT projection. Right, Topographic projections after an ipsilateral ITD tuning shift of $36 \mu \mathrm{sec}$ in the ICX. Neurons on the $\mathrm{c} 45$ Transect exhibit best ITDs of $\mathrm{c} 9 \mu$ sec and are predicted to receive abnormal inputs from ICCls neurons representing these ITDs (arrow). Parallel anatomical rearrangements mediating shifts at other ICX locations are not shown.

adult, is shown in Figure $6 \mathrm{~A}$. The volume of the injection site, defined as the region of dense extracellular label, was $2.7 \times 10^{6}$ $\mu \mathrm{m}^{3}$ (slightly smaller than the mean for all cases, $4.4 \times 10^{6}$ $\mu \mathrm{m}^{3}$; Table 1). After BDA injections confined to the ICX, labeled neurons were found in the ICX, the ICCls, and to a much lesser extent the ICC core (for the number of neurons labeled in each nucleus, see Table 1). In this report, we focus on the labeling of somata in the ICCls (e.g., Fig. 6B, C), which was used to infer the topography of the ICCls-ICX projection, and the labeling of varicosity-containing axon segments in the OT (Fig. 6D), which was used to infer the topography of the ICX-OT projection.

\section{Topography of the ICCls-ICX projection in normal adults and juveniles}

In normal adults, the location of labeled ICCls neurons varied systematically with location of the ICX injection site (Fig. 7). For injections on the 0 Transect, labeled somata were clustered in the rostral ICCls (Fig. 7 $A$ ), near the representation of $0 \mu \mathrm{sec}$ ITD (Fig. 2B). Only a few scattered cells were found at more caudal ICCls locations. For injections on the 45 Transect, most neurons were found more caudally in the ICCls (Fig. 7B), near the representation of $\mathrm{c} 45 \mu \mathrm{sec}$ ITD (Fig. $2 B$ ). In addition, labeled axon terminals were found in each case in a restricted region of the OT corresponding to the representation of the ITD value at the ICX injection site. Note that labeled ICX and ICC core neurons are not shown in the figures. In juvenile owls, similar patterns of ICCls and OT labeling were observed (Fig. 8). Despite a trend toward greater labeling in juveniles, there was no significant difference in the absolute number of labeled neurons in juveniles and adults (mean, 73 cells per injection for juveniles, 41 for adults; ANOVA; $p=0.09$ ).

Labeling patterns were quantified by measuring the rostrocaudal position of each ICCls neuron relative to the ICC core staining and creating a distribution of labeled cell positions for each case (Fig. 9). In adults, 0 Transect injections resulted in cell distributions with median positions ranging from 5 to $10 \%$ caudal, with the large majority of neurons located in the rostral third of the ICCls. In contrast, c45 Transect injections resulted in distributions with median positions of $42-79 \%$ caudal, with $<10 \%$ of the cells located in the rostral third of the ICCls. To summarize this data, combined distributions representing all 0 or c45 Transect injections were compiled from the individual adult cases (Fig. 9C, hatched bars). The median cell position for the combined 0 Transect distribution was $10 \%$ caudal, close to the known representation of $0 \mu \mathrm{sec}$ in the ICCls (20\% caudal, calculated from Eq. 1; Fig. 9C, arrowhead). The median position for the combined c45 Transect distribution was $70 \%$ caudal, close to the known representation of $\mathrm{c} 45 \mu \mathrm{sec}(73 \%$ caudal; Fig. $9 C$, arrowhead).

Distributions for juvenile cases were not different from those for adults. Individual juvenile and adult distributions were equally broad (IQR for 0 Transect injections: $37 \pm 6 \%$ for juveniles, $n=$ 3 ; $30 \pm 7 \%$ for adults, $n=4 ; p>0.20$, unpaired $t$ test; for $\mathrm{c} 45$ Transect injections: $42 \pm 3 \%$ for juveniles, $n=3 ; 28 \pm 17 \%$ for adults, $n=3 ; p>0.23$, unpaired $t$ test). Correspondingly, combined distributions calculated across juvenile cases (Fig. 9C, gray bars $)$ were not different in shape from those for adults $\left(\chi^{2}\right.$ tests for juvenile vs adult combined distributions; 0 Transect: $\chi^{2}=5.4$, df $=6, p>0.25$; 445 Transect: $\chi^{2}=6.2$, df $\left.=5, p>0.25\right)$.

To determine whether the observed topography was consistent with a projection that linked sites of like ITD tuning in the two nuclei, we calculated for each normal adult case the mean rostrocaudal position of the labeled somata and the ITD value represented at that ICCls position, using Equation 1. We then compared this ITD value with the best ITD value measured at the ICX injection site for the same case (Table 2). Across cases, the mean mismatch between these ITD values was only $8.3 \mu \mathrm{sec}$, or $3.6 \%$ of the $\approx 225 \mu \mathrm{sec}$ range of ITD represented in each ICX. Together, these data indicate that the ICCls-ICX projection exhibits essentially the same topography in juveniles and normal adults, and serves to link sites of similar ITD tuning in the two nuclei.

\section{Topography of the ICCIs-ICX projection in prism-reared owls}

To determine whether the topography of the ICCls-ICX projection was changed by prism experience, BDA injections were made in prism-reared owls after the maximal ITD tuning shift had taken place. Injections were targeted for the same anatomical 

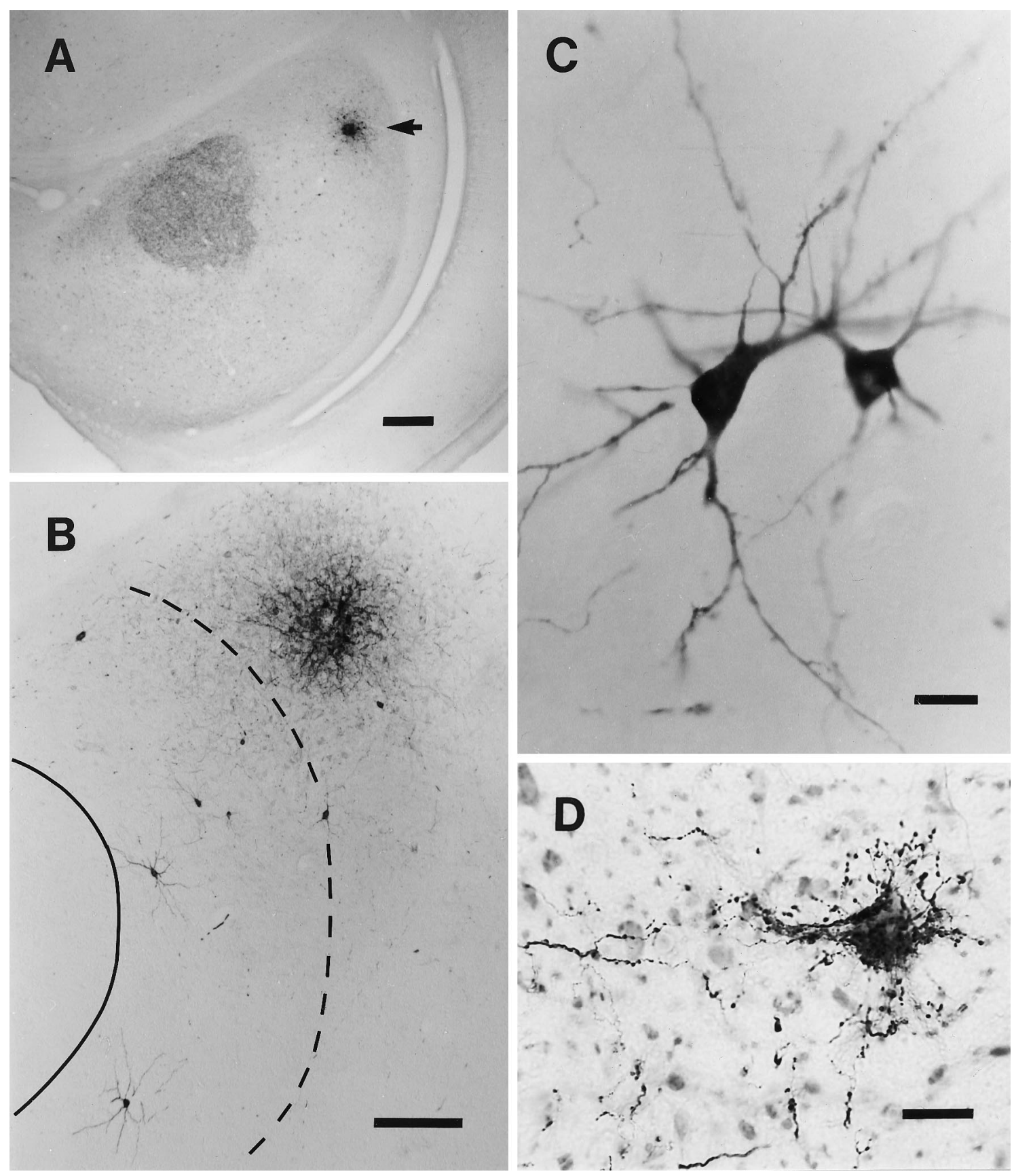

Figure 6. BDA labeling in the IC and OT. A, BDA injection site (arrow) at the representation of $\mathrm{c} 3 \mu \mathrm{sec}$ ITD in the ICX of a normal adult (Case GoL). Section is counterstained for $\mathrm{CaBP}$ to show the ICC core and lateral boundary of the ICX. Scale bar, $500 \mu \mathrm{m}$. The orientation is the same as shown in Figure $2 B$. B. Higher power view of a different BDA injection site (Case PmR) at the same anatomical location, showing retrogradely labeled somata in the ICCls. Solid line, Lateral boundary of the ICC core from neighboring CaBP-stained section. Dashed line, ICCls-ICX boundary. Scale bar, $250 \mu \mathrm{m}$. Orientation as in $A$. $C$, Labeled ICCls neurons at high magnification. Scale bar, $25 \mu \mathrm{m}$. $D$, Anterogradely labeled fibers in the OT enveloping a Nissl-stained neuron in the deep tectal layers. Scale bar, $25 \mu \mathrm{m}$.

locations as in normal owls and were made with the same iontophoresis parameters. Injection sites were recovered at the same anatomical locations as in normal owls: 0 Transect injections were located $18 \pm 8 \%$ caudal in the ICX of prism-reared owls and $15 \pm$ $5 \%$ caudal in normal adults. c45 Transect injections were located $46 \pm 4 \%$ caudal in prism-reared owls and $49 \pm 5 \%$ caudal in normal owls. The volumes of the injection sites in normal adults and prism-reared owls were not significantly different (Table 1) (ANOVA; $p=0.96)$.

\section{Cases with contralateral ITD tuning shifts}

We first present data for the ICX with a contralateral ITD tuning shift $(n=4)$. Injections were made on the 0 Transect, and the mean best ITD observed at these injection sites was c40 $\mu \mathrm{sec}$ (range, 30-54 $\mu \mathrm{sec}$ ). The anatomical hypothesis predicts that neurons at this location receive inputs from caudal locations in the ICCls where $\mathrm{c} 40 \mu \mathrm{sec}$ is represented (Fig. 5, middle panel).

Results from three of the injections are shown in Figure 10; 
Table 1. Characteristics of ICX injection sites

\begin{tabular}{|c|c|c|c|c|c|c|c|c|}
\hline \multirow[b]{2}{*}{ Case } & \multirow[b]{2}{*}{ Prisms } & \multirow{2}{*}{$\begin{array}{l}\text { Injection } \\
\text { location }^{a}\end{array}$} & \multirow{2}{*}{\multicolumn{2}{|c|}{ Tuning shift ${ }^{b}$}} & \multirow{2}{*}{$\begin{array}{l}\text { Injection volume } \\
\left(\mu \mathrm{m}^{3} \times 10^{6}\right)\end{array}$} & \multicolumn{3}{|c|}{ No. of labeled cells } \\
\hline & & & & & & $\mathrm{ICX}^{c}$ & ICCls & Core \\
\hline \multicolumn{9}{|c|}{ Normal adults } \\
\hline GoL & - & 0 & - & & 2.7 & 18 & 46 & 11 \\
\hline GoR & - & 0 & - & & 7.3 & 41 & 36 & 2 \\
\hline WiL & - & 0 & - & & 5.3 & 15 & 51 & 10 \\
\hline WiR & - & 0 & - & & 5.6 & 12 & 17 & 4 \\
\hline $96 \mathrm{R}$ & - & $\mathrm{c} 45$ & - & & 4.1 & 55 & 99 & 18 \\
\hline $\mathrm{RaR}$ & - & $\mathrm{c} 45$ & - & & 2.6 & 2 & 26 & 6 \\
\hline \multirow[t]{2}{*}{$\mathrm{RaL}$} & - & $\mathrm{c} 45$ & - & & 1.9 & 3 & 13 & 0 \\
\hline & & & & Mean: & 4.2 & 21 & 41 & 7 \\
\hline \multicolumn{9}{|c|}{ Juveniles } \\
\hline $\mathrm{PmL}$ & - & 0 & - & & 6.7 & 22 & 100 & 17 \\
\hline PmR & - & 0 & - & & 8.0 & 28 & 74 & 18 \\
\hline $\mathrm{CaL}$ & - & 0 & - & & 3.8 & 54 & 93 & 12 \\
\hline $\mathrm{CaR}$ & - & $\mathrm{c} 45$ & - & & 2.1 & 56 & 57 & 3 \\
\hline $25 \mathrm{~L}$ & - & $\mathrm{c} 45$ & - & & 0.5 & 5 & 16 & 4 \\
\hline \multirow[t]{2}{*}{$25 \mathrm{R}$} & - & $\mathrm{c} 45$ & - & & 6.7 & 41 & 99 & 19 \\
\hline & & & & Mean: & 4.5 & 29 & 73 & 12 \\
\hline \multicolumn{9}{|c|}{ Prism-reared } \\
\hline PiR & $\mathrm{R} 23^{\circ}$ & 0 & Contralateral & & 3.9 & 21 & 108 & 4 \\
\hline $\mathrm{CkL}$ & $\mathrm{L}_{2} 3^{\circ}$ & 0 & Contralateral & & 5.7 & 76 & 134 & 33 \\
\hline LoL & $\mathrm{L}_{2} 3^{\circ}$ & 0 & Contralateral & & 1.1 & 30 & 97 & 4 \\
\hline \multirow[t]{2}{*}{$\mathrm{HaR}$} & $\mathrm{R} 23^{\circ}$ & 0 & Contralateral & & 6.2 & 46 & 139 & 11 \\
\hline & & & & Mean: & 4.2 & 43 & $120^{*}$ & 13 \\
\hline LoR & $\mathrm{L} 23^{\circ}$ & 0 & Ipsilateral & & 5.7 & 18 & 26 & 0 \\
\hline $\mathrm{HaL}$ & $\mathrm{R} 23^{\circ}$ & 0 & Ipsilateral & & 4.6 & 29 & 34 & 7 \\
\hline PkR & $\mathrm{L}_{2} 3^{\circ}$ & $\mathrm{c} 45$ & Ipsilateral & & 4.9 & 48 & 87 & 8 \\
\hline \multirow[t]{2}{*}{$\mathrm{NiR}$} & $\mathrm{L}_{2} 3^{\circ}$ & c45 & Ipsilateral & & 4.2 & $\underline{13}$ & 48 & 0 \\
\hline & & & & Mean: & 4.8 & 27 & 49 & 4 \\
\hline
\end{tabular}

${ }^{a}$ Physiologically defined transect on which injection was made (see Materials and Methods).

${ }^{b}$ Direction of tuning shift toward contralateral- or ipsilateral-ear leading ITDs.

${ }^{c}$ Excluding region within $400 \mu \mathrm{m}$ of injection center.

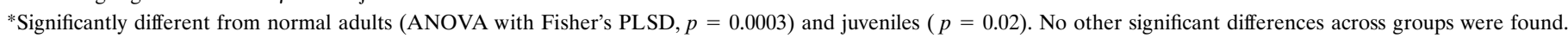

results from the fourth were similar. In each case, the region of robust labeling was expanded caudally relative to normal adults with matched injection sites (Fig. $7 A$ ). In addition, each injection labeled approximately three times more ICCls neurons than in normal adults (Table 1). The increase in labeling was specific for the ICCls; there was no significant increase in the number of labeled ICC core cells or of retrogradely labeled neurons in the ICX (Table 1) (ANOVA with Fisher's PLSD; $p=0.27$ for ICC core, and $p=0.10$ for ICX).

Calculation of the distribution of labeled ICCls neurons confirmed these observations (Fig. 11). The distribution for each prism-reared case was significantly different from the combined distribution for 0 Transect injections in normal adults $\left(\chi^{2}\right.$ test, HaR: $\chi^{2}=240.7, p<0.005$; PiR: $\chi^{2}=150.0, p<0.005$; CkL: $\chi^{2}$ $=316, p<0.005$; LoL: $\chi^{2}=144, p<0.005$; df for all cases $=5$ ). Prism-reared distributions were more caudally centered than normal adult distributions (medians were $36-47 \%$ caudal for prism-reared cases and 5-10\% for normal cases) and had dramatically more cells in ICCls positions $\geq 30 \%$ caudal $(54-82 \%$ of cells in prism-reared cases vs $6-28 \%$ in control cases). Large numbers of labeled neurons were also present in the rostral ICCls of prism-reared cases, resulting in a broadening of the distributions (IQR: $44-48 \%$ for prism-reared cases; $23-39 \%$ for control cases; $p<0.003$; unpaired $t$ test). Correspondingly, the combined distribution for all prism-reared cases (Fig. 11 B, gray bars) contained many more caudally situated neurons than the comparable distribution for normal adults (black bars) and included large numbers of neurons at the representations of both $\mathrm{c} 40$ and $0 \mu \mathrm{sec}$ (arrowheads).

\section{Cases with ipsilateral ITD tuning shifts}

In two prism-reared owls, BDA injections were made on the 0 Transect in the ICX with an ipsilateral ITD tuning shift (mean best ITD at these injection sites, i40 $\mu \mathrm{sec}$ ). Because ipsilateral-ear leading ITD values are represented rostrally in the ICCls, a rostral expansion of retrograde labeling was predicted in these cases.

The results of one such injection are shown in Figure $12 \mathrm{~A}$ (Left Side). For comparison, an injection on the opposite side of the same owl where a contralateral ITD tuning shift had occurred (Right Side) is also shown. Despite a strong caudal expansion of labeling on the contralaterally shifted side, the bulk of labeling on 

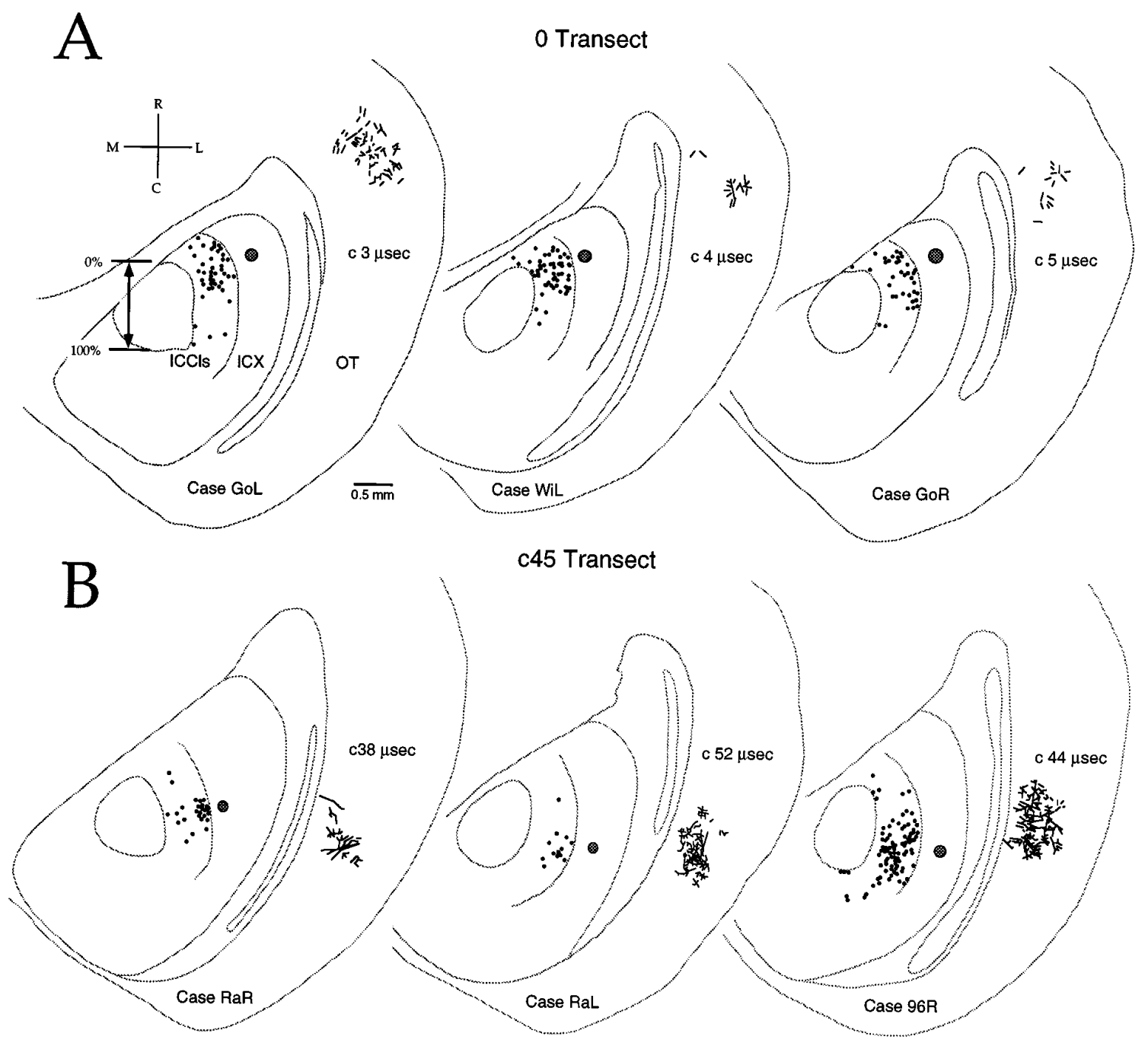

Figure 7. ICCls labeling after ICX injections in normal adult owls. $A$, Representative cases with injections on the 0 Transect. Gray circles, ICX injection sites. Dots, All labeled neurons in the ICCls. Labeled neurons in the ICX and ICC core are not shown. Line segments, Anterogradely labeled fibers with varicosities. Subdivision boundaries are from the level of the injection site. The best ITD recorded at each injection site is indicated. Scale for calculating rostrocaudal position of labeled ICCls neurons is from Figure $2 B . B$, Injections on the c45 Transect.

the ipsilaterally shifted side was observed very rostrally in the ICCls. The same result was observed in a second owl (not shown). When the distributions of labeled cells were calculated for the two owls (Fig. 12B), it was apparent that the caudal expansion of ICCls labeling on the contralaterally shifted sides (hatched bars) was not replicated on the ipsilaterally shifted sides (gray bars). Furthermore, the distributions for ipsilaterally shifted sides were shifted rostrally relative to the combined distribution for normal adults $\left(\chi^{2}\right.$ tests, HaL: $\chi^{2}=64.36, p<0.005$; LoR: $\chi^{2}=13.23, p<$ 0.05 ; $\mathrm{df}=6$ for both cases). No increase was observed in these cases in the number of retrogradely labeled neurons in the ICC core (Table 1), another potential source of ipsilateral-ear leading ITD tuning (Brainard and Knudsen, 1993).

In two cases, injections were made on the c45 Transect in the ICX with an ipsilateral ITD tuning shift (Fig. 13). Neurons at these injection sites had become tuned for $\mathrm{c} 17 \mu \mathrm{sec}$ (Case NiR) and c6 $\mu \mathrm{sec}$ (Case PkR), instead of the normal c45 $\mu$ sec ITD (i.e., there was a mean shift of $34 \mu$ sec ipsilateral-ear leading). The hypothesis predicted that neurons at these sites receive input from abnormally rostral ICCls locations, where the new best ITD values were represented (Fig. 5, right panel).
Indeed, more labeled neurons were found in the rostral ICCls in these cases than after matched injections in normal adult owls (shown in Fig. 7B). The cell position distribution for each prismreared case (Fig. 13B, open bars) was significantly different from the combined distribution for normal adults (black bars) ( $\chi^{2}$ tests, NiR: $\chi^{2}=36.7, p<0.005$; PkR: $\chi^{2}=29.5, p<0.005$; df $=6$ ). The prism-reared distributions were more rostrally centered than normal (medians, 50 and 58\% caudal for prism-reared, 70\% caudal for normal adults) and had a larger percentage of labeled neurons located in the rostral $30 \%$ of the ICCls (32 and $27 \%$ of neurons for prism-reared, $8-12 \%$ for normal adults). Correspondingly, the combined histogram for the prism-reared cases (gray bars) contained many neurons at the representation of $\mathrm{c} 11 \mu \mathrm{sec}$, the mean best ITD measured at the injection sites; however, it also contained many neurons at the representation of $\mathrm{c} 45 \mu \mathrm{sec}$, the normal best ITD for the injection sites. As a result, the distribution for the prism-reared cases was broader than that for normal adults (the IQR was $53 \%$ for prism-reared and $28 \%$ for normals).

The observed differences in ICCls-ICX topography between juvenile, normal adult, and prism-reared owls are summarized schematically in Figure 14. 
A

0 Transect
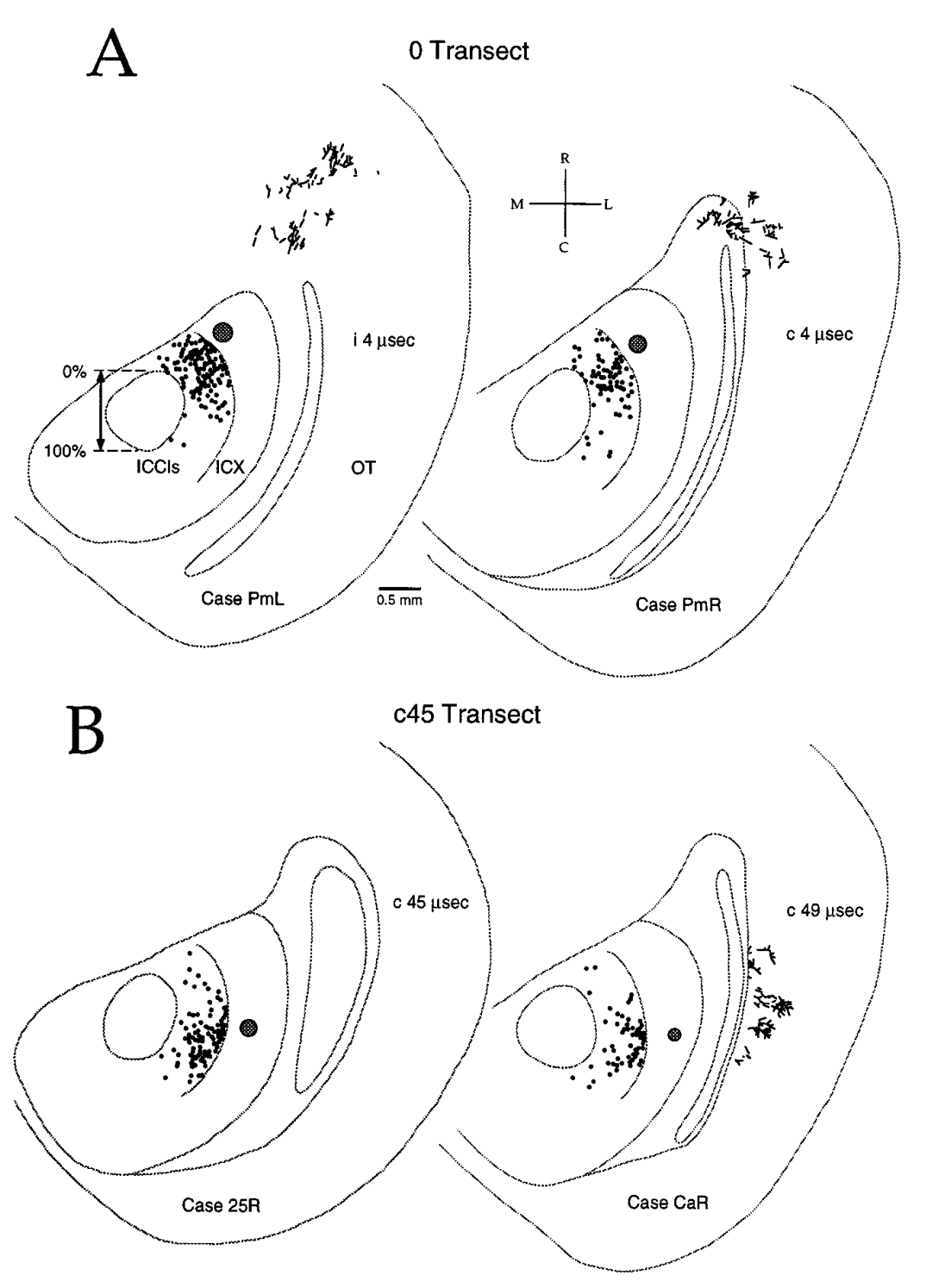

Figure 8. ICCls labeling after ICX injections in juveniles $A$, Representative injections on the 0 Transect. $B$, Injections on the c45 Transect. Conventions as in Figure 7. Injection sites were at the same rostrocaudal position as for normal adults ( 0 Transect: $17 \pm 2 \%$ caudal for juveniles, $15 \pm 5 \%$ for adults; c45 Transect: $43 \pm 3 \%$ for juveniles, $49 \pm 5 \%$ for adults) and were the same average volume (Table 1).

\section{Comparison of ICCls-ICX topography in prism-reared and juvenile owls}

Because juvenile owls represent the state before prism attachment, comparison of labeling patterns in juveniles and prismreared adults may provide insight into how abnormal ICCls-ICX topography develops during prism-rearing. We calculated the average number of labeled neurons at different ICCls locations for juvenile and prism-reared cases with anatomically matched injection sites and compared this labeling using the metric $(P-$ $J) /(P+J)$ (see Materials and Methods). Positive values of this metric indicate that more neurons were observed per prismreared case than per juvenile case, and negative values indicate more neurons per juvenile case than per prism-reared case. Results are shown in Figure 15.

We first compared 0 Transect injections in juveniles with those in prism-reared cases with contralateral ITD tuning shifts (i.e., the cases in Figs. $8 A$ and 10). Relative to juveniles, the prismreared cases showed increased numbers of labeled neurons at caudal ICCls locations and decreased numbers of labeled neurons at rostral locations. For ICCls positions $\geq 68 \%$ caudal, which corresponds to the representation of ITDs $\geq \mathrm{c} 40 \mu \mathrm{sec}$ (the mean best ITD at the injection site after prism-rearing), labeling in- creased from 5.0 neurons/injection in juveniles to 25.5 neurons/ injection in prism-reared adults, a 5.1-fold increase. For ICCls positions $\leq 20 \%$ caudal, corresponding to ITDs more ipsilateralear leading than $0 \mu \mathrm{sec}$, the original best ITD for this injection site, labeling decreased from 56.3 neurons/injection in juveniles to 33.5 neurons/injection in prism-reared adults, a 0.6 -fold decrease. Both of these changes were significant (ANOVA; increase, $p=$ 0.001; decrease, $p=0.02$.)

We next compared c45 Transect injections in juveniles and in prism-reared cases with ipsilateral ITD tuning shifts (the cases in Figs. $8 B$ and 13). Relative to juveniles, the prism-reared cases showed increased labeling at rostral ICCls locations and decreased labeling at caudal locations. For ICCls locations $\leq 33 \%$ caudal, which correspond to best ITDs $\leq \mathrm{c} 11 \mu \mathrm{sec}$ (the mean best ITD at the injection site after prism-rearing), labeling increased 2.7-fold from 7.7 neurons/injection in juveniles to 20.5 neurons/ injection in prism-reared adults. For ICCls locations $\geq 73 \%$ caudal, which correspond to best ITDs $\geq \mathrm{c} 45 \mu \mathrm{sec}$, the original best ITD for these injection sites, labeling decreased from 27.3 neurons/injection to 19.5 neurons/injection, a 0.7 -fold decrease. There were too few cases to determine whether these nominal changes were statistically significant. 

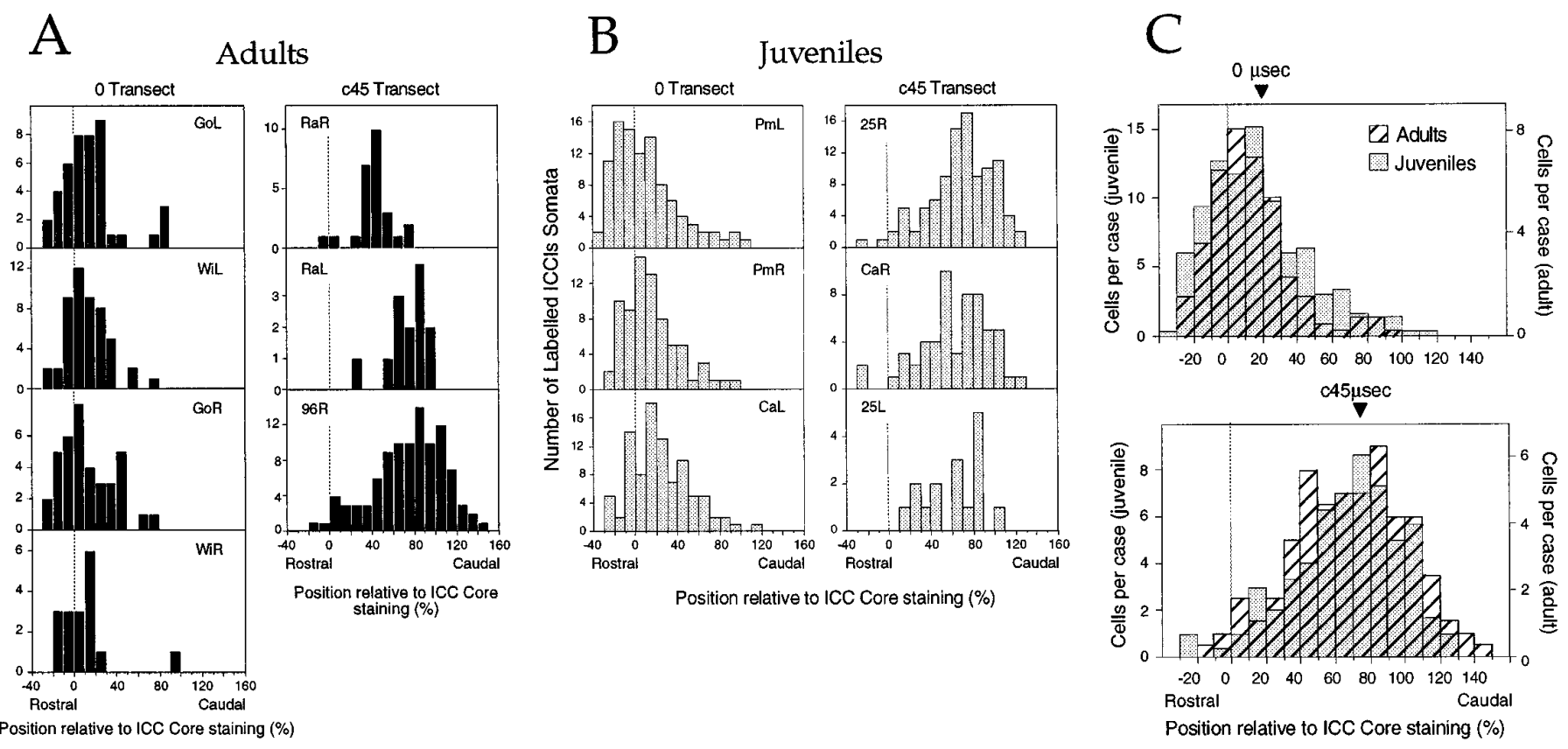

Figure 9. Quantification of the rostrocaudal position of labeled ICCls neurons in normal adults and juveniles. $A$, Distribution of cell positions for each normal adult case. Abscissa corresponds to the scale in Figure $7 A$, which was the scale used to reconstruct the ITD map in the ICCls (Fig. $2 C$ ). $B$, Distributions for juvenile cases. $C$, Comparison of combined distributions for all normal adult (hatched bars) and all juvenile ( gray bars) cases. Top, 0 Transect injections; bottom, c45 Transect injections. Triangles indicate ICCls location where 0 or c45 $\mu$ sec ITD is represented. Note different vertical scales for adults and juveniles.

Table 2. ICCls-ICX topography in normal adult cases

\begin{tabular}{|c|c|c|c|c|}
\hline Case & $\begin{array}{l}\text { Best ITD at ICX } \\
\text { injection site } \\
(\mu \mathrm{sec})\end{array}$ & $\begin{array}{l}\text { Mean ICCls } \\
\text { cell position }{ }^{a} \\
(\% \text { caudal })\end{array}$ & $\begin{array}{l}\text { ITD represented } \\
\text { at this position } \\
(\mu \mathrm{sec})\end{array}$ & $\begin{array}{l}\text { Difference from } \\
\text { best ITD } \\
(\mu \mathrm{sec})\end{array}$ \\
\hline GoL & c3 & 11 & $\mathrm{i} 6.8$ & 9.8 \\
\hline GoR & c5 & 13 & i5.3 & 10.3 \\
\hline WiL & $\mathrm{c} 4$ & 13 & i5.3 & 9.3 \\
\hline WiR & 0 & 11 & $\mathrm{i} 6.8$ & 6.8 \\
\hline $96 \mathrm{R}$ & c44 & 74 & $\mathrm{c} 46.5$ & -2.5 \\
\hline $\mathrm{RaR}$ & c38 & 43 & $\mathrm{c} 18.3$ & 19.7 \\
\hline \multirow[t]{2}{*}{$\mathrm{RaL}$} & c52 & 75 & $\mathrm{c} 47.5$ & 4.5 \\
\hline & & & & Mean: 8.3 \\
\hline
\end{tabular}

${ }^{a}$ From cell position distributions in Fig. 9.

${ }^{b}$ Using Equation 1.

In cases with 0 Transect injections and ipsilateral ITD tuning shifts (Fig. 12), similar results were observed: labeling in the caudal ICCls decreased markedly relative to matched injections in juveniles, whereas labeling in the most rostral ICCls regions increased slightly. We could not calculate the exact labeling increase that occurred in the ICCls region representing the ITD values adopted at the injection site during prism-rearing, however, because the representation of such large ipsilateral-ear leading ITDs in the rostral zone of the ICCls is unknown.

Topography of the ICX-OT projection in prism-reared owls Our hypothesis predicted that the topography of the projection from the ICX to the OT would be unchanged by prism-rearing. To test this prediction, we analyzed the pattern of terminal labeling in the OT after BDA injections in the ICX (Fig. 16). Labeled fibers were short, often highly branched, and had prominent en passant and terminal varicosities. In some cases, fibers enveloped large somata in the deep tectal layers (Fig. 6D), somata with the morphology of layer 13 cells (Knudsen, 1982). Because only two labeled neurons were ever observed in the OT (after 21 ICX injections), these terminals are almost certainly anterogradely labeled ICX afferents synapsing in the OT.

BDA injections on the 0 Transect labeled axon terminals in the rostral tectum (Fig. 16, left side), whereas injections on the c45 Transect labeled axon terminals at more caudal tectal locations (Fig. 16, right side). This labeling pattern is consistent with the known topography of the ICX-OT projection (Knudsen and Knudsen, 1983). There were no apparent differences in the location of labeled terminals in prism-reared versus normal owls for either ICX injection location (Fig. 16, top vs bottom rows). This observation was verified quantitatively by plotting the position of each terminal field center relative to the position of the corresponding injection site within the ICX (Fig. 17). In normal owls 


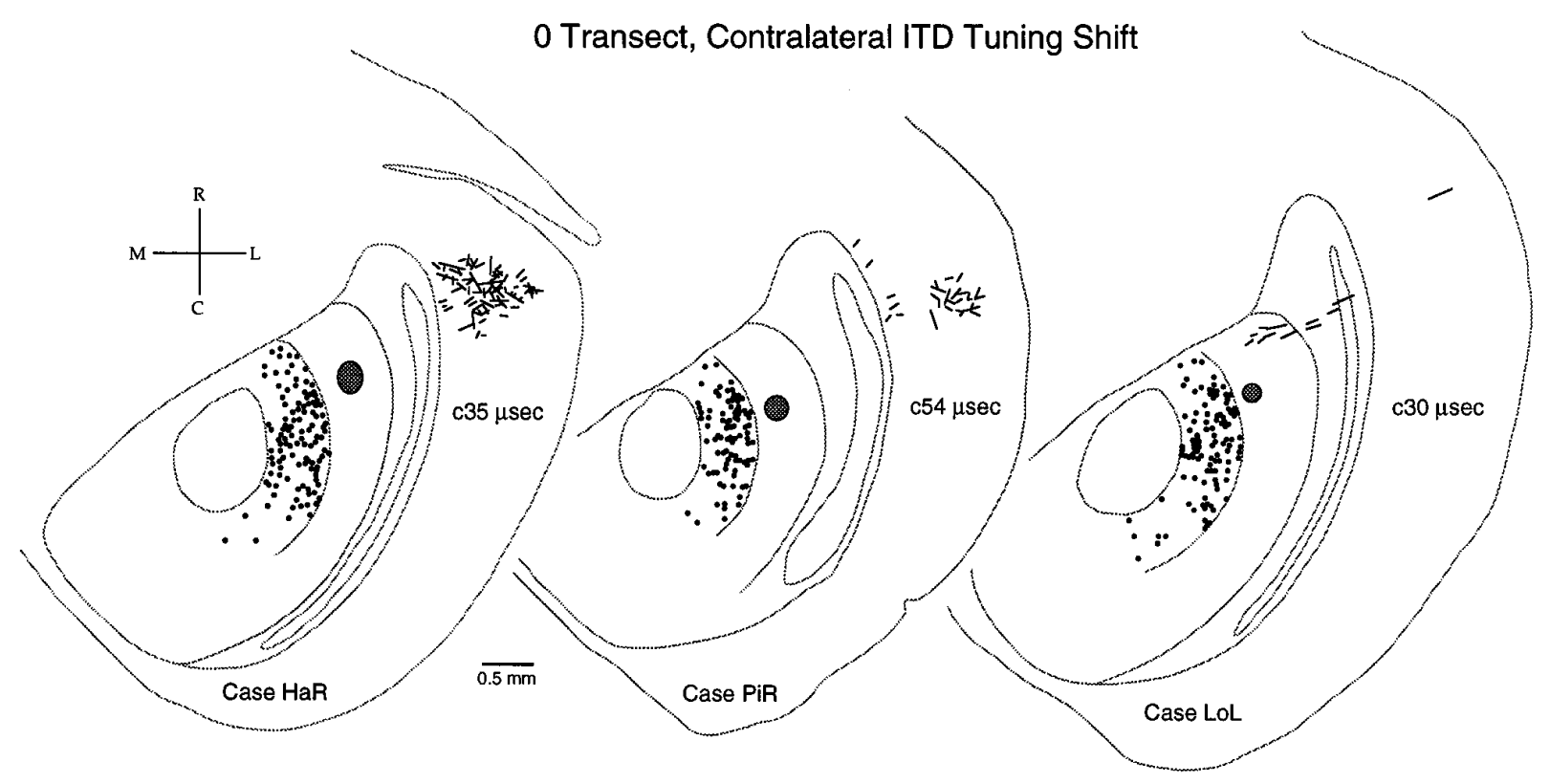

Figure 10. ICCls labeling after ICX injections in representative prism-reared cases with contralateral ITD tuning shifts. Injections were made on the 0 Transect and should be compared with the injections made in normal owls in Figures $7 A$ and $8 A$. ITD tuning was shifted toward contralateral-ear leading ITDs at these injection sites (best ITD at each injection site is indicated).

(open circles), there was a linear relationship between the position of the ICX injection site and the position of the resulting afferent label in the OT. In prism-reared owls (Fig. 17, squares), all but one case fell within the envelope of the control data (gray area), and this aberrant case was actually displaced in the wrong direction to explain the tectal ITD tuning shift in this owl. Thus, the topography of the ICX-OT projection appeared unchanged by prism-rearing (as schematized in Fig. 14).

\section{DISCUSSION}

We have identified an anatomical modification that is likely to contribute to experience-dependent modification of ITD tuning in the owl's auditory space map. In a previous study (Brainard and Knudsen, 1993), it was suggested that the ITD tuning shift in the OT of prism-reared owls resulted from synaptic plasticity at the level of the ICX, with little or no additional plasticity occurring between the ICX and the OT. Consistent with this hypothesis, we found large differences between normal and prism-reared barn owls in the topography of the projection from the ICCls to the ICX (Figs. 7, 8, 10, 12, 13), but no apparent differences in the topography of the projection from the ICX to the OT (Figs. 16, 17).

\section{Topography of the ICCls-ICX projection in normal adults and juveniles}

In normal adults, BDA injections in the ICX labeled neuronal somata in a restricted region of the ICCls whose location varied systematically with position of the injection site in the ICX (Fig. 7). This topography was found to link sites of like ITD tuning in the two nuclei (Table 2), consistent with the hypothesis that the topography of this projection is an important factor contributing to the ITD tuning of ICX neurons.

In juveniles aged 58-64 d, retrograde labeling patterns were similar to those observed in normal adults (Figs. 8, 9), indicating that by this age the topography of the ICCls-ICX projection had essentially achieved its mature form, at least in the horizontal
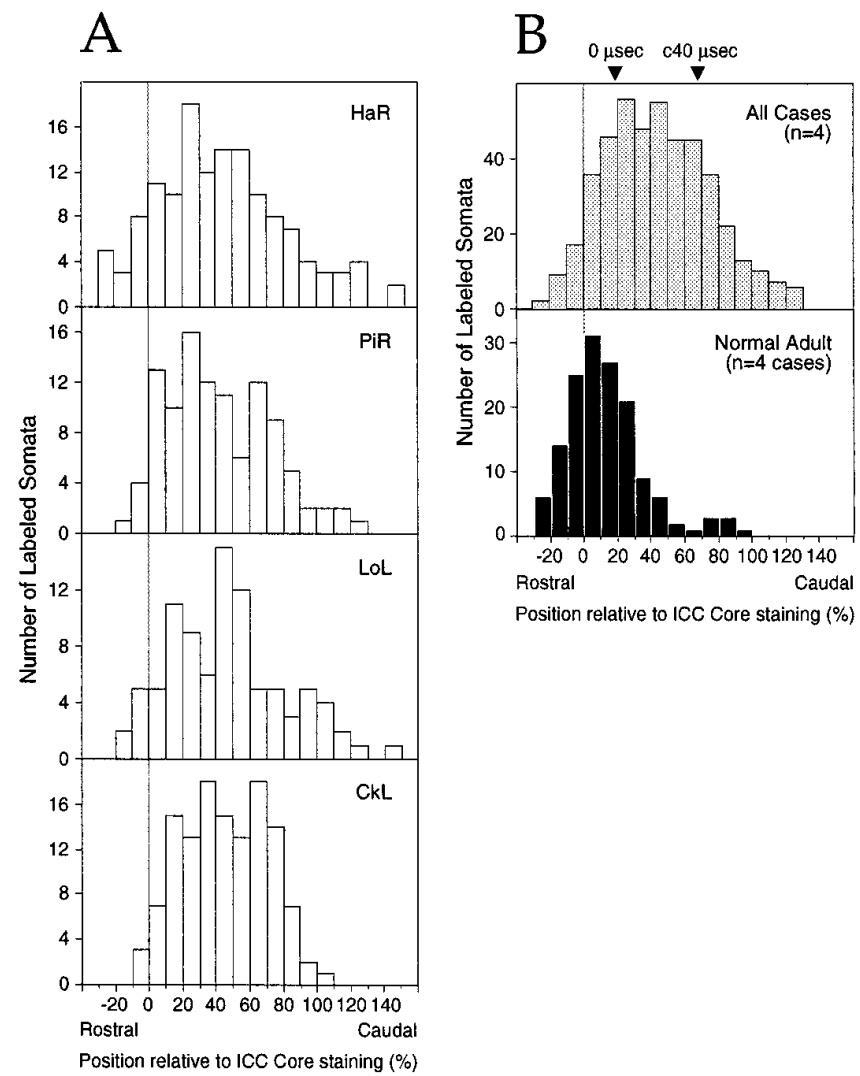

Figure 11. Quantification of ICCls labeling in all cases with contralateral ITD tuning shifts. $A$, Distributions of labeled cell position for individual cases. $B$, Combined histogram for all four prism-reared cases (gray bars) and for normal adults with matched injection sites (black bars). Triangles, ICCls positions corresponding to the normal best ITD for this injection site $(0 \mu \mathrm{sec})$ and to the mean best ITD adopted after prism-rearing (c40 $\mu \mathrm{sec})$. 

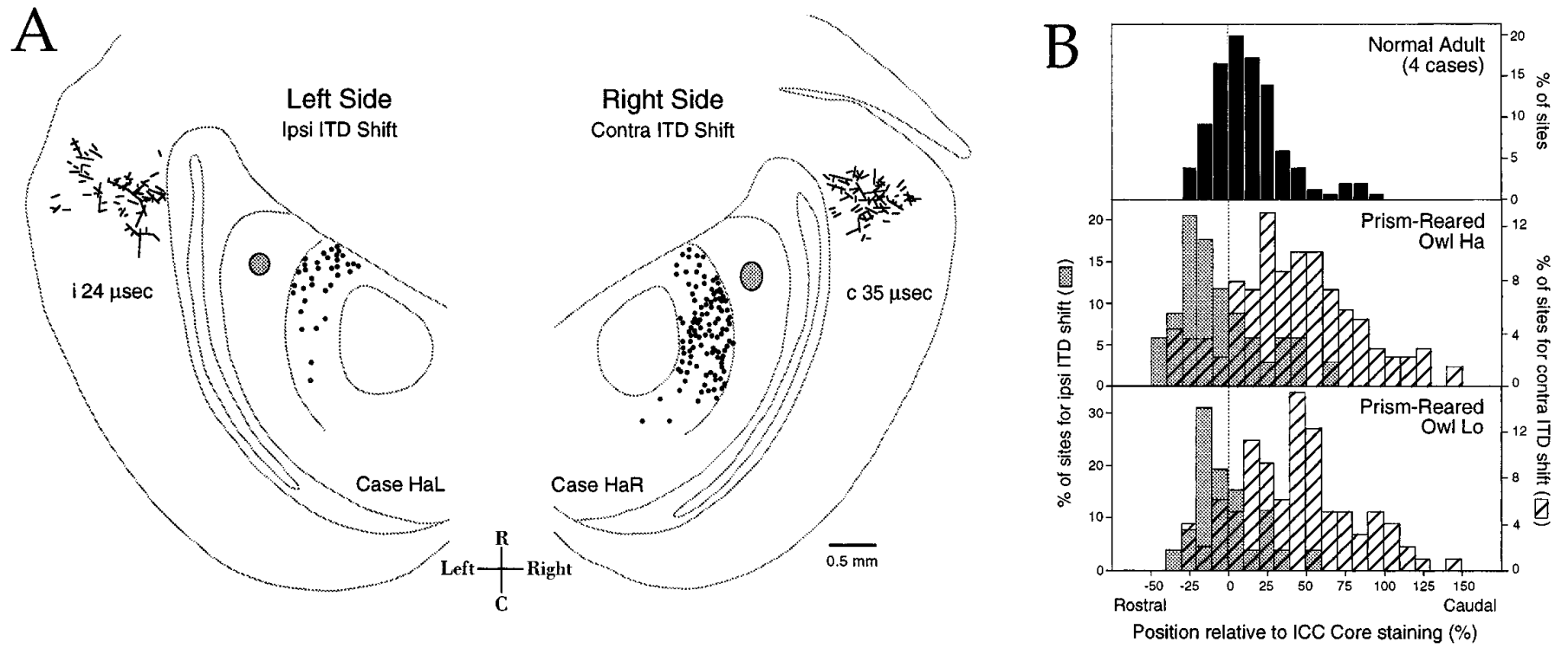

Figure 12. ICCls labeling after ICX injections in cases with ipsilateral ITD tuning shifts. $A$, ICCls labeling resulting from injections at matched anatomical locations in the two ICX of one prism-reared owl (Owl Ha). Injections are on the 0 Transect. The left side, where tuning was shifted toward ipsilateral-ear leading ITDs, showed labeled cells concentrated in the most rostral portions of the ICCls. The right side, where tuning was shifted toward contralateral-ear leading ITD values, showed a caudal expansion of ICCls labeling (this case is also shown in Fig. 10). B, Positions of labeled ICCls neurons in $\mathrm{Owl} \mathrm{Ha}$ and in another owl with similar results $(\mathrm{Owl} \mathrm{Lo})$. Gray bars, Side with ipsilateral ITD tuning shift. Hatched bars, Side with contralateral ITD tuning shift. Black bars, Combined histogram from normal adults with matched injection sites.
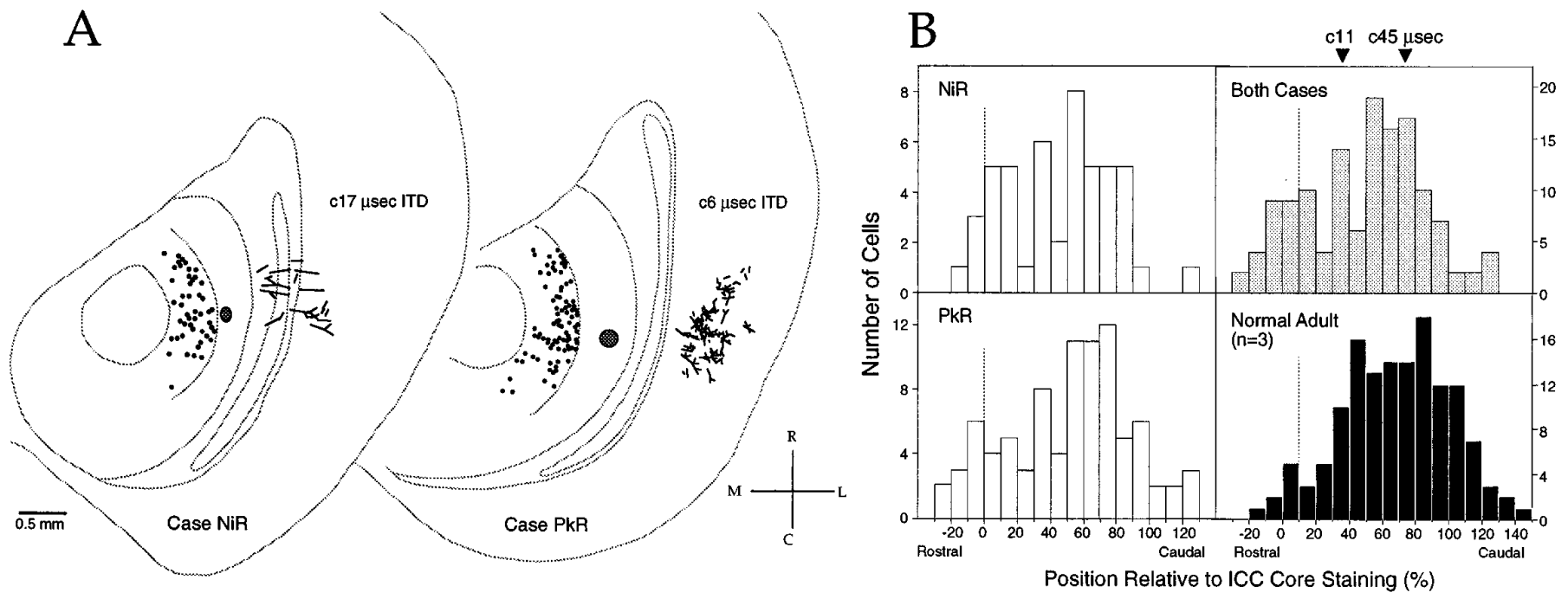

Figure 13. ICCls labeling after injections on the c45 Transect in cases with ipsilateral ITD tuning shifts. The anatomical hypothesis for these cases is shown in Figure 5, right panel. A, ICCls labeling for each of the two prism-reared cases. These cases should be compared with controls with matched injection sites (Figs. 7B, 8B). B, Positions of labeled ICCls neurons for these cases (open bars). Gray bars, Combined distribution. Triangles, ICCls positions corresponding to the normal best ITD for these injection sites ( $45 \mu \mathrm{sec})$ and to the mean best ITD adopted after prism-rearing in these cases $(\mathrm{c} 11 \mu \mathrm{sec})$. Black bars, Combined distribution for matched injections in normal adults.

plane. Consistent with this observation, the shape of ITD tuning curves and the topography of the ITD map in the ICX and OT were indistinguishable in juveniles and normal adults (Figs. 1, 2, 4).

\section{Topography of the ICCls-ICX projection in prism-reared owls}

ICX injections in prism-reared owls produced patterns of ICCls backfill that were different from those in juveniles and normal adults, and these abnormal patterns were consistent with adaptive remodeling of the ICCls-ICX projection. When injections were made at ICX sites that had acquired responses to abnormally contralateral-ear leading ITDs, we observed retrograde labeling at abnormally caudal ICCls locations, where contralateral-ear leading ITDs are represented (Fig. 10). When injections were made at ICX sites that had acquired responses to abnormally ipsilateral-ear leading ITDs, labeling was observed at abnormally rostral ICCls locations, where more ipsilateral-ear leading ITDs are represented (Figs. 12, 13). Such abnormal labeling was a prediction of our hypothesis (Fig. 5). Unexpectedly, we also observed labeling at topographically normal locations in all prism-reared owls. 

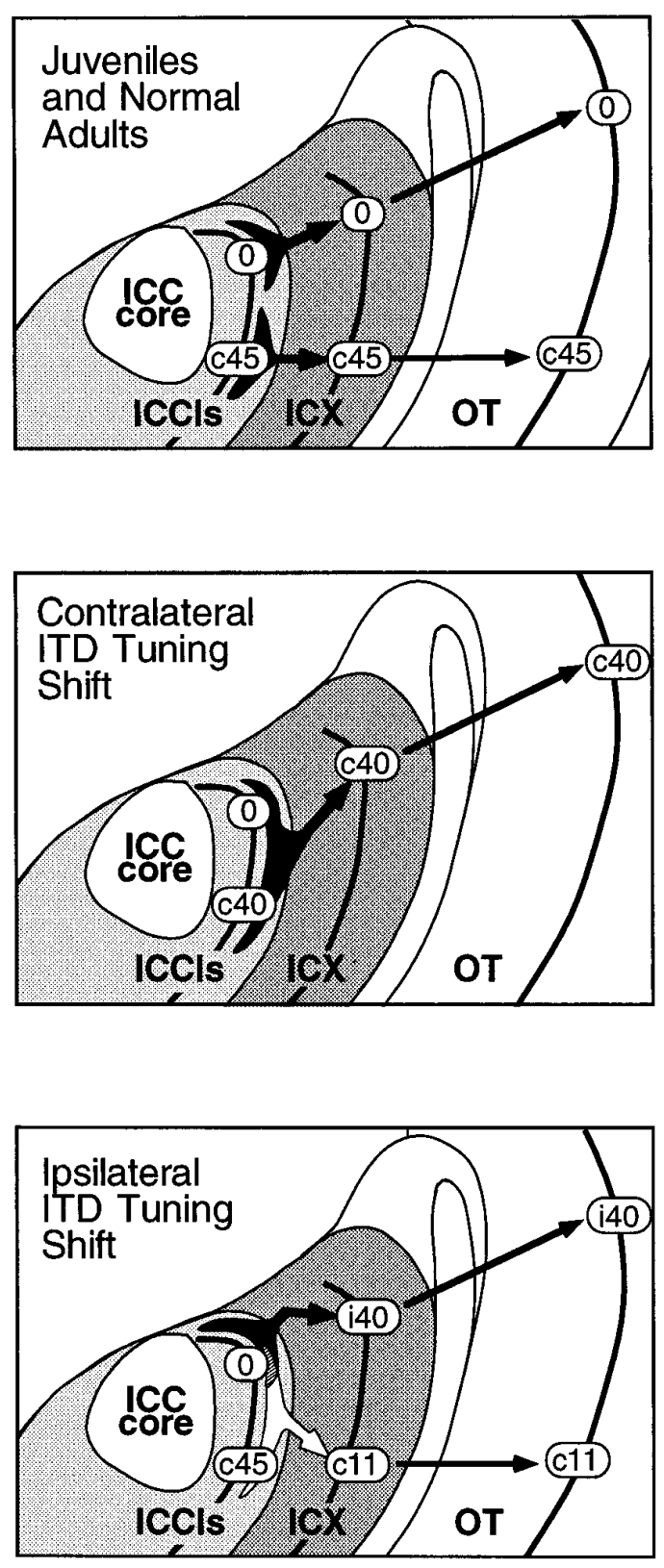

Figure 14. Summary of the anatomical modifications caused by prismrearing. Top, ICCls regions providing input to the representations of 0 and $\mathrm{c} 45 \mu \mathrm{sec}$ ITD in the ICX of normal adults and juveniles. Middle, After contralateral ITD tuning shifts, sites on the 0 Transect (which exhibited a mean best ITD of c40 $\mu$ sec) received abnormal input from caudal ICCls regions, where contralateral-ear leading ITDs are represented. At the same time, strong labeling continued to be observed at normal ICCls locations. Bottom, After ipsilateral ITD tuning shifts, sites on the c45 Transect (which exhibited a mean best ITD of c11 $\mu \mathrm{sec}$ ) received abnormal input from rostral ICCls regions, where more ipsilateral-ear leading ITDs are represented (white). Similarly, sites on the 0 Transect (which showed a mean best ITD of i40 $\mu \mathrm{sec}$ ) received abnormal input from extremely rostral ICCls regions (black). In both cases, topographically normal labeling was also observed. There was no apparent effect of prism-rearing on the topography of the ICX-OT projection.

\section{Interpretation of topographically abnormal labeling in prism-reared owls}

The presence of topographically abnormal ICCls labeling in prism-reared owls is consistent with the hypothesis that ICX sites acquire novel ICCls inputs during prism-rearing to mediate shifted ITD tuning. Indeed, for 0 Transect injections in cases with contralateral ITD tuning shifts, and for $\mathrm{c} 45$ Transect injections in cases with ipsilateral tuning shifts, many of the abnormally situated ICCls neurons were located at or beyond the ICCls representation of the shifted best ITD value for the injection site (Figs. 11,13 ). Thus, the abnormally situated neurons were appropriate to drive shifted responses at the ICX injection site, suggesting that these neurons are likely to provide synaptic input to ICX neurons. Whether this was also true for 0 Transect injections in cases with ipsilateral tuning shifts was unclear, because the abnormally situated neurons were located in the rostral extreme of the ICCls (Fig. 12), where the map of ITD is not known.

\section{Interpretation of topographically normal labeling in prism-reared owls}

Labeling at topographically normal ICCls locations is more difficult to interpret. One interpretation is that this labeling reflects the persistence of normally targeted ICCls-ICX synapses in prism-reared owls, even after large ITD tuning shifts have occurred and responses to normal ITD values have been dramatically reduced (e.g., Fig. 4B). If this were the case, a mechanism must exist in the ICX to prevent the expression of responses to normal ITDs that would be mediated by these synapses. This could be accomplished, for example, by a reduction in the efficacy of these synapses or by suppression of normal responses by local inhibitory circuits.

An alternative interpretation for the labeling of ICCls neurons at topographically normal locations is that these neurons were labeled because they extend axons of passage through the injection site without forming functional synapses. This could occur, for example, if ICCls axons were remodelled during prismrearing to traverse their normal target zones without synapsing on their way to new, abnormal termination zones (e.g., Udin, 1983). Visualization of ICCls axons and the distribution of their boutons will be necessary to determine which of these interpretations is correct.

\section{Development of abnormal topography during prism-rearing}

To gain some insight into how abnormal ICCls-ICX topography might develop during prism-rearing, we compared labeling patterns in prism-reared cases with those in juveniles, which represent the state of the system before prism attachment (Fig. 15). Relative to juveniles with matched injection sites, prism-reared cases showed a greater absolute number of labeled neurons in the ICCls region where shifted ITD values were represented and fewer labeled neurons in ICCls regions where normal ITD values were represented. These results suggest a developmental model in which ICCls neurons representing the shifted ITD values for a given ICX site start to project more heavily to that location during prism-rearing, while ICCls neurons representing the normal ITD values for that site reduce their projection. The elaboration and retraction of axonal branches implicit in such a model are a hallmark of activity-dependent development in many systems (Sretavan and Shatz, 1986; Nakamura and O'Leary, 1989; Udin, 1989; Callaway and Katz, 1990; O'Rourke and Fraser, 1990; Simon and O'Leary, 1992; Antonini and Stryker, 1993b).

An alternative interpretation arises from the observation that retrograde labeling can be influenced by neuronal activity (Singer et al., 1977), perhaps reflecting a link between tracer uptake and vesicle recycling (Holtzman et al., 1971). If ICCls-ICX synaptic 
0 Transect
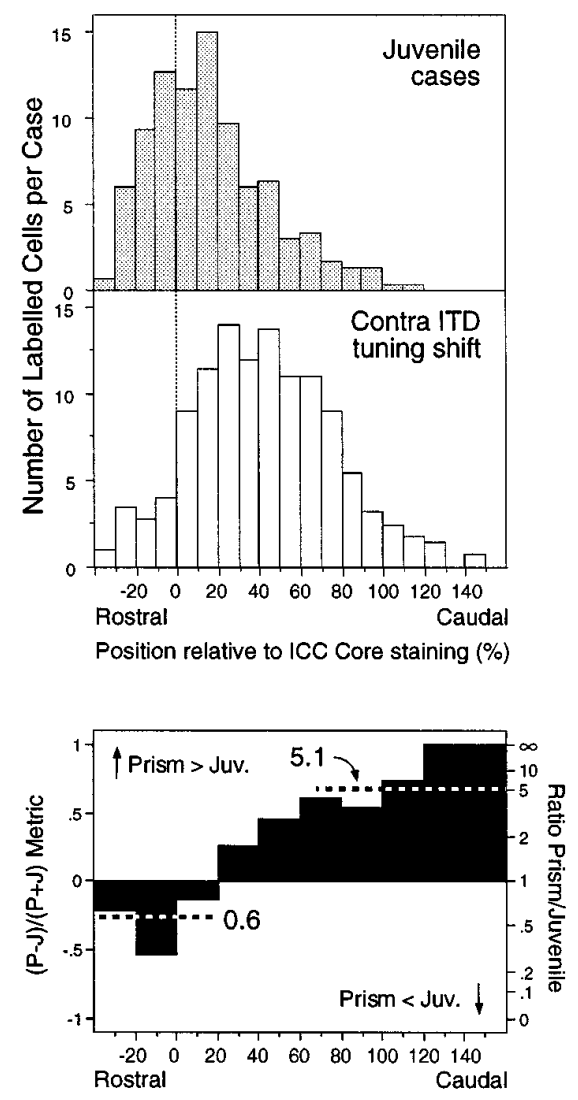

Position relative to ICC Core staining (\%)
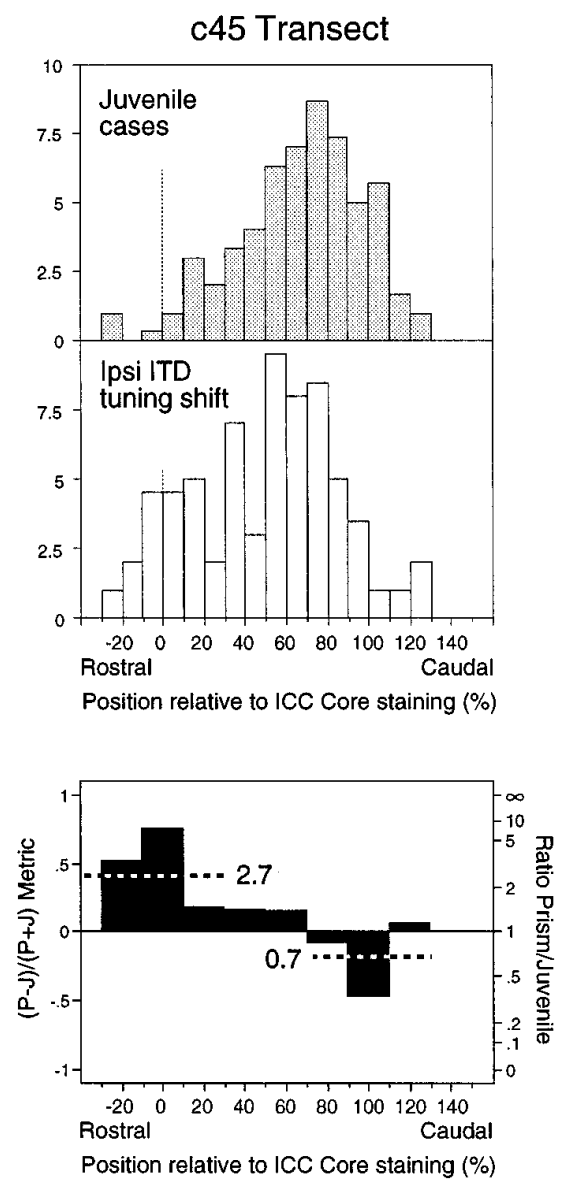

Figure 15. Comparison of ICCls labeling for juveniles and prism-reared adults with matched injection sites. Gray bars, Mean ICCls labeling for juvenile cases ( $n=3$ for each transect). Ordinate, mean number of labeled cells per case. Open bars, Mean labeling for prism-reared cases $(n=4$ for 0 Transect; $n=2$ for c45 Transect). Black bars, $(P-$ $J) /(P+J)$ metric computed for different intervals of ICCls position (see Materials and Methods). Positive values of the metric indicate more labeled neurons in prism-reared than in juvenile cases; negative values indicate more neurons in juvenile than in prism-reared cases. For reference, the ratio (neurons per prism-reared case/neurons per juvenile case) is also shown. Dashed lines, Mean ratios for specific ICCls regions (see Results). gain were regulated in a manner that affected vesicle recycling (for example, by regulation of the probability of release), then BDA injections might be expected to label preferentially those ICCls neurons making high-gain synapses at the injection site. Because of this possibility, labeling differences between juveniles, normal adults, and prism-reared adults could in principle reflect differences in synaptic gain rather than in axonal projection patterns. We consider this possibility unlikely, however, because BDA was coinjected with a detergent, which should minimize any role of activity in regulating uptake. Visualization of ICCls axons will be required, however, to determine unambiguously whether axonal remodeling in fact occurs during prism-rearing.

\section{Critical discussion of methods}

Two main factors complicate the interpretation of this study. First, retrograde labeling is biased against the detection of lightly labeled somata, and therefore we cannot exclude the possibility that the true topography of the ICCls-ICX projection may be somewhat less precise than that described here. This issue does not detract from our main conclusions that the ICCls-ICX projection is primarily topographic and that this topography is altered adaptively by prism-rearing.

A second complication is our observation of a small number of labeled neurons in the ICC Core (Table 1), suggesting that a sparse projection may exist from the ICC Core to the ICX. The ICC Core has not been shown to project to the ICX, but it does project contralaterally to the ICCls (Takahashi et al., 1989), raising the alternate possibility that our injections encroached on the ICCls. None of the injection sites in this report was observed to extend into the ICCls, as defined with $\mathrm{CaBP}$ staining. It is possible, however, that the ICCls actually extended slightly outside the CaBP-defined border or that the effective size of the injection site was greater than that measured. These possibilities notwithstanding, spillover into the ICCls would have directly labeled neurons at the topographically normal ICCls location for the ICX injection site. Thus, this artifact would have led to an underestimate of the amount of topographical change that actually occurred in the ICCls-ICX projection of prism-reared owls.

\section{Comparison with other models of experience-dependent plasticity}

The basic finding that systematic remapping of receptive field properties can be caused by reorganization of a topographic afferent projection was demonstrated many years ago in the primary visual cortex of Siamese cats. Despite an aberrant retinogeniculate projection that leads to a disordered representation of visual space in the LGN, ordered visuotopy is apparent in Area 17 (Hubel and Wiesel, 1971). The anatomical basis for this reestablishment of visuotopy is a topographical reorganization of the geniculocortical projection relative to normal cats (Shatz and LeVay, 1978).

Anatomical reorganization occurs in many systems in response to altered patterns of sensory experience, including monocular deprivation (Hubel et al., 1977; Antonini and Stryker, 1993a), strabismus (Lowel and Singer, 1992), focal retinal lesions (Darian-Smith and Gilbert, 1994, 1995), and somatosensory deafferentation (Florence and Kaas, 1995). The anatomical plasticity reported here is different from most other examples in that the 


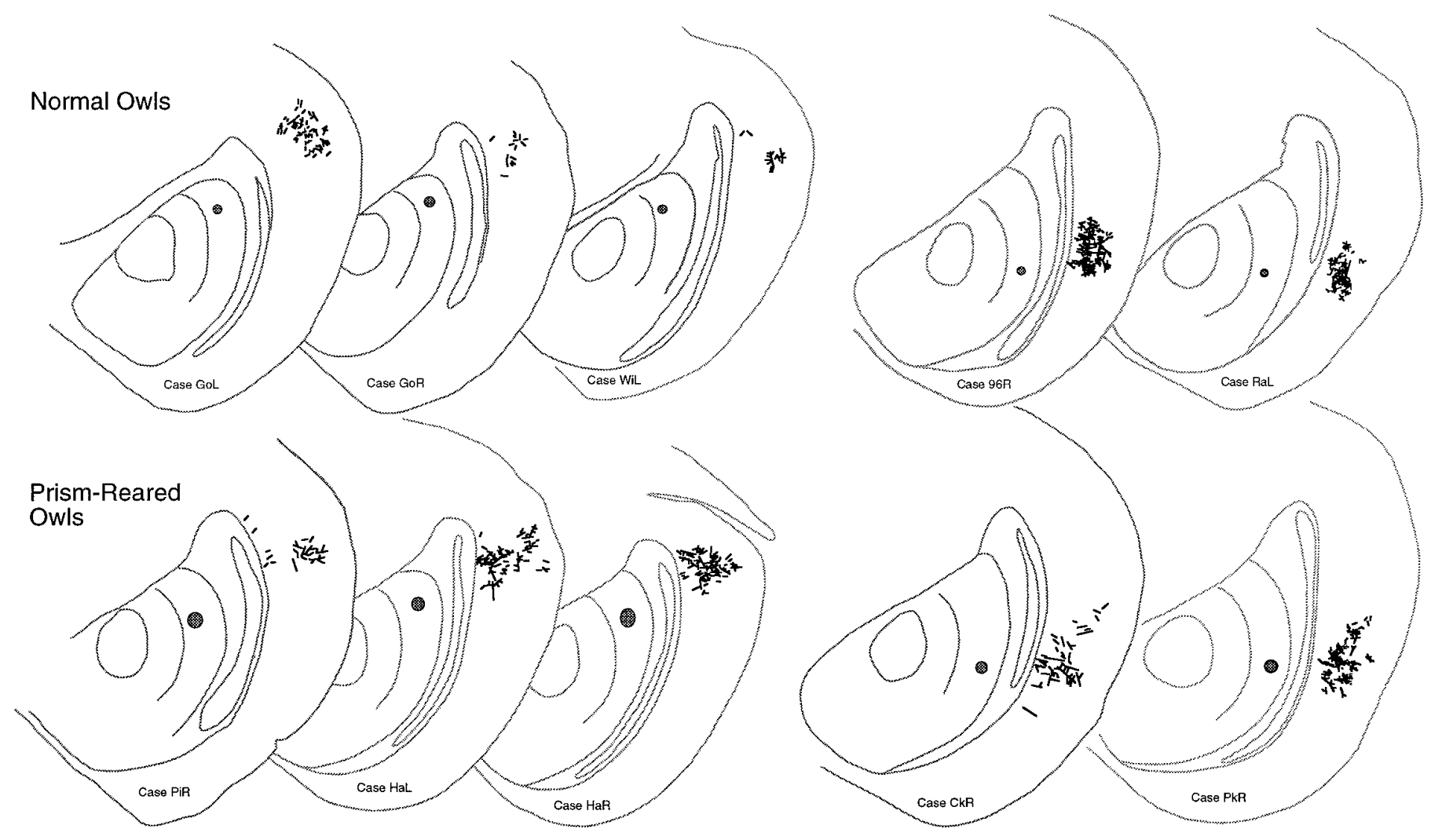

Figure 16. Topography of the ICX-OT projection in representative normal and prism-reared owls. Location of anterogradely labeled afferents (line segments) in the OT after ICX injections on the 0 Transect (left) or the c45 Transect (right). Top row, Normal owls; bottom row, prism-reared owls. No difference in topography was evident.

manipulation used to induce plasticity, a change in the correspondence between sound localization cues and visual field locations, is one that occurs during normal development as the head grows

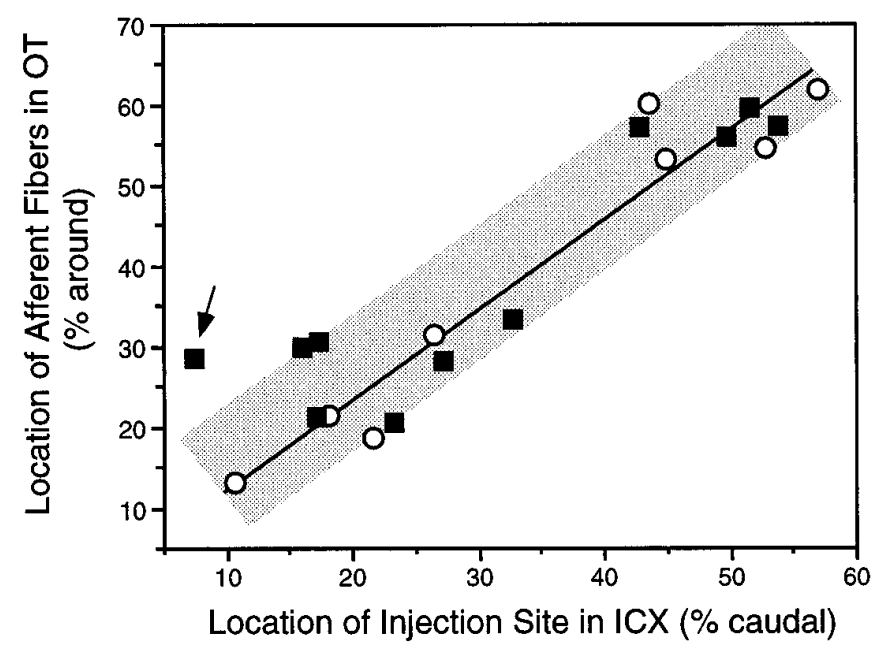

Figure 17. Quantification of the topography of the ICX-OT projection in normal and prism-reared owls. The location of the geometric center of afferent labeling in the OT is plotted against the location of the injection site in the ICX for each normal case (open circles). The line is a linear regression to the normal data $\left(r^{2}=0.934 ; p<0.001\right)$. Data from prism-reared cases (squares) fall within the normal envelope (gray region), with one exception (arrow).
(Moore and Irvine, 1979; Knudsen et al., 1984; Carlile, 1991). In addition, because the maps of ITD are well described in the owl's IC, we were able to show that the direction and magnitude of anatomical reorganization was appropriate to mediate the observed physiological plasticity.

Our findings are particularly reminiscent of the anatomical modification that occurs during alignment of binocular VRFs in the OT of Xenopus laevis (Udin and Fawcett, 1988). Rotation of the contralateral eye in Xenopus causes a remapping of ipsilateraleye VRFs in the OT (Gaze et al., 1970). This remapping is caused by a topographical change in the crossed isthmotectal projection, which provides ipsilateral eye input to the tectum: after eye rotation, retrograde labeling shows that each tectal site receives input from an abnormal locus in the nucleus isthmi. At the same time, similar to the results presented here, retrograde labeling at the topographically normal locus is preserved (Udin and Keating, 1981). It has been shown electrophysiologically that this residual normal labeling corresponds to normally targeted synapses that remain present in the OT but are functionally suppressed (Brickley et al., 1994).

\section{Conclusion}

We have shown that the topography of the projection from the ICCls to the ICX in the barn owl is adaptively altered by rearing owls with altered visual experience. Because the auditory spatial tuning of ICX neurons determines, in large part, the spatial tuning of neurons in the owl's OT, the reorganization of the ICCls-ICX projection is ultimately responsible for the experience-driven align- 
ment of auditory and visual maps of space in the tectum (Knudsen, 1982).

\section{REFERENCES}

Antonini A, Stryker MP (1993a) Rapid remodeling of axonal arbors in the visual cortex. Science 260:1819-1821.

Antonini A, Stryker MP (1993b) Development of individual geniculocortical arbors in cat striate cortex and effects of binocular impulse blockade. J Neurosci 13:3549-3573.

Brainard MS, Knudsen EI (1993) Experience-dependent plasticity in the inferior colliculus: a site for visual calibration of the neural representation of auditory space in the barn owl. J Neurosci 13:4589-4608.

Brainard MS, Knudsen EI (1995a) Dynamics of visually guided auditory plasticity in the optic tectum of the barn owl. J Neurophysiol 73:595-613.

Brainard MS, Knudsen EI (1995b) Creating a unified representation of visual and auditory space in the brain. Annu Rev Neurosci 18:19-43.

Brickley SG, Keating MJ, Grant S (1994) Experience-dependent mechanism of binocular map plasticity in Xenopus: incongruent connections are masked by retinal input. Neurosci Lett 182:13-16.

Callaway EM, Katz LC (1990) Emergence and refinement of clustered horizontal connections in cat striate cortex. J Neurosci 10:1134-1153.

Carlile S (1991) The auditory periphery of the ferret: postnatal development of acoustic properties. Hear Res 51:265-278.

Darian-Smith C, Gilbert CD (1994) Axonal sprouting accompanies functional reorganization in adult cat striate cortex. Nature 368:737-740.

Darian-Smith C, Gilbert CD (1995) Topographic reorganization in the striate cortex of the adult cat and monkey is cortically mediated. J Neurosci 15:1631-1647.

Feldman DE (1997) Anatomical and pharmacological correlates of learning in the neural representation of auditory space in the barn owl. $\mathrm{PhD}$ thesis, Stanford University.

Feldman DE, Knudsen EI (1994) Topography of the projection from the central to the external nucleus of the inferior colliculus in normal and prism-reared barn owls. Soc Neurosci Abstr 20:456.8.

Feldman DE, Knudsen EI (1996) Anatomical basis for the adjustment of interaural time difference (ITD) tuning in the external nucleus of the inferior colliculus (ICX) of juvenile barn owls: selective pruning or synaptogenesis? Soc Neurosci Abstr 22:161.9.

Florence SL, Kaas JH (1995) Large-scale reorganization at multiple levels of the somatosensory pathway follows therapeutic amputation of the hand in monkeys. J Neurosci 15:8083-8095.

Fox, K (1994) The cortical component of experience-dependent synaptic plasticity in the rat barrel cortex. J Neurosci 14:7665-7679.

Gaze RM, Keating MJ, Szekely G, Beazley L (1970) Binocular interaction in the formation of specific intertectal neuronal connections. Proc R Soc Lond [Biol] 175:107-147.

Haresign T, Moiseff A (1988) Early growth and development of the common barn-owl's facial ruff. Auk 105:699-705.

Holtzman E, Freeman AR, Kashner LA (1971) Stimulation-dependent alterations in peroxidase uptake at lobster neuromuscular junctions. Science 173:733-736.

Hubel DH, Wiesel TN (1971) Aberrant visual projections in the Siamese cat. J Physiol (Lond) 218:33-62.

Hubel DH, Wiesel TN, LeVay S (1977) Plasticity of ocular dominance columns in monkey striate cortex. Philos Trans R Soc Lond Ser B 278:377-409.

King AJ (1993) A map of auditory space in the mammalian brain: neural computation and development. Exp Physiol 78:559-590.

Knudsen EI (1982) Auditory and visual maps of space in the optic tectum of the owl. J Neurosci 2:1177-1194.

Knudsen EI (1983) Subdivisions of the inferior colliculus in the barn owl (Tyto alba). J Comp Neurol 218:174-186.

Knudsen EI (1985) Experience alters the spatial tuning of auditory units in the optic tectum during a sensitive period in the barn owl. J Neurosci 5:3094-3109.

Knudsen EI, Brainard MS (1991) Visual instruction of the neural map of auditory space in the developing optic tectum. Science 253:85-87.
Knudsen EI, Knudsen PF (1983) Space-mapped auditory projections from the inferior colliculus to the optic tectum in the barn owl (Tyto alba). J Comp Neurol 218:187-196.

Knudsen EI, Esterly SD, Knudsen PF (1984) Monaural occlusion alters sound localization during a sensitive period in the barn owl. J Neurosci 4:1001-1011.

LeVay S, Wiesel TN, Hubel DH (1980) The development of ocular dominance columns in normal and visually deprived monkeys. J Comp Neurol 191:1-51.

Lowel S, Singer W (1992) Selection of intrinsic horizontal connections in the visual cortex by correlated neuronal activity. Science 255:209-212.

Mogdans J, Knudsen EI (1992) Adaptive adjustment of unit tuning to sound localization cues in response to monaural occlusion in developing owl optic tectum. J Neurosci 12:3473-3484.

Moiseff A, Konishi M (1981) Neuronal and behavioral sensitivity to binaural time difference in the owl. J Neurosci 1:40-48.

Moore DR, Irvine DRF (1979) A developmental study of the sound pressure transformation by the head of the cat. Acta Otolaryngol 87:434-440.

Nakamura H, O'Leary DDM (1989) Inaccuracies in initial growth and arborization of chick retinotectal axons followed by course corrections and axon remodeling to develop topographic order. J Neurosci 9:3776-3795.

Olsen JF, Knudsen EI, Esterly SD (1989) Neural maps of interaural time and intensity differences in the optic tectum of the barn owl. J Neurosci 9:2591-2605.

O'Rourke NA, Fraser SE (1990) Dynamic changes in optic fiber terminal arbors lead to retinotopic map formation: an in vivo confocal microscopic study. Neuron 5:159-171.

Shatz CJ, LeVay S (1978) Siamese cat: altered connections of visual cortex. Science 204:328-330.

Simon DK, O'Leary DDM (1992) Development of topographic order in the mammalian retinocollicular projection. J Neurosci 12:1212-1232.

Singer W, Hollander H, Vanegas H (1977) Decreased peroxidase labeling of lateral geniculate neurons following deafferentation. Brain Res 120:133-137.

Sretavan DW, Shatz CJ (1986) Prenatal development of retinal ganglion cell axons: segregation into eye-specific layers within the cat's lateral geniculate nucleus. J Neurosci 6:234-251.

Takahashi TT, Konishi M (1988) Projections of the cochlear nuclei and nucleus laminaris to the inferior colliculus of the barn owl. J Comp Neurol 274:190-211.

Takahashi TT, Carr CE, Brecha N, Konishi M (1987) Calcium binding protein-like immunoreactivity labels the terminal field of nucleus laminaris in the barn owl. J Neurosci 7:1843-1856.

Takahashi TT, Wagner H, Konishi M (1989) Role of commissural projections in the representation of bilateral auditory space in the barn owl's inferior colliculus. J Comp Neurol 281:545-554.

Udin SB (1983) Abnormal visual input leads to development of abnormal axon trajectories in frogs. Nature 301:336-338.

Udin SB (1989) Development of the nucleus isthmi in Xenopus, II: Branching patterns of contralaterally projecting isthmotectal axons during maturation of binocular maps. Visual Neurosci 2:153-163.

Udin SB, Keating MJ (1981) Plasticity in a central nervous pathway in Xenopus: anatomical changes in the isthmotectal projection after larval eye rotation. J Comp Neurol 203:575-594.

Udin SB, Fawcett JW (1988) Formation of topographic maps. Annu Rev Neurosci 11:289-327.

Wagner H, Takahashi T, Konishi M (1987) Representation of interaural time difference in the central nucleus of the barn owl's inferior colliculus. J Neurosci 7:3105-3116.

Wiesel TN, Hubel DH (1963) Single-cell responses in striate cortex of kittens deprived of vision in one eye. J Neurophysiol 2:1003-1017.

Zar JF (1996) Biostatistical analysis, 3rd edition. Upper Saddle River, NJ: Prentice-Hall. 